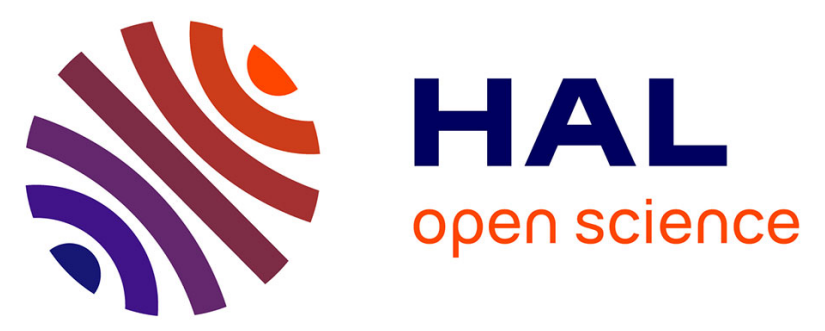

\title{
Assessment of anthropogenic and natural factors on Cheliff river waters (North-West of Algeria) at two contrasted climatic seasons
}

Batoul Benkaddour, Fatiha Abdelmalek, Ahmed Addou, Thierry Noguer, Laurence Voutquenne-Nazabadioko, Florence Vouvé

\section{To cite this version:}

Batoul Benkaddour, Fatiha Abdelmalek, Ahmed Addou, Thierry Noguer, Laurence VoutquenneNazabadioko, et al.. Assessment of anthropogenic and natural factors on Cheliff river waters (NorthWest of Algeria) at two contrasted climatic seasons. International Journal of Environmental Research, 2019, 13 (6), pp.925-941. 10.1007/s41742-019-00223-7 . hal-02963018

\section{HAL Id: hal-02963018 https://hal.sorbonne-universite.fr/hal-02963018}

Submitted on 9 Oct 2020

HAL is a multi-disciplinary open access archive for the deposit and dissemination of scientific research documents, whether they are published or not. The documents may come from teaching and research institutions in France or abroad, or from public or private research centers.
L'archive ouverte pluridisciplinaire HAL, est destinée au dépôt et à la diffusion de documents scientifiques de niveau recherche, publiés ou non, émanant des établissements d'enseignement et de recherche français ou étrangers, des laboratoires publics ou privés. 
Assessment of anthropogenic and natural factors on Cheliff river waters (North-

West of Algeria) at two contrasted climatic seasons

Batoul BENKADDOUR ${ }^{\mathrm{a}, \mathrm{b}, \mathrm{c}}$, Fatiha ABDELMALEK ${ }^{\mathrm{a}}$, Ahmed ADDOU ${ }^{\mathrm{a}}$, Thierry

NOGUER $^{\mathrm{b}, \mathrm{c}}$, Dominique AUBERT ${ }^{\mathrm{d}, \mathrm{e}}$, Florence VOUVÉ ${ }^{\mathrm{b}, \mathrm{c}}$

${ }^{\text {a }}$ Laboratoire des Sciences et Techniques de l'Environnement et de la Valorisation (STEVA), Université de Mostaganem, 27000 Mostaganem, Algérie

b Université de Perpignan Via Domitia, Biocapteurs-Analyses-Environnement, 66860 Perpignan, France.

${ }^{\mathrm{c}}$ Laboratoire de Biodiversité et Biotechnologies Microbiennes, USR 3579 Sorbonne Universités (UPMC) Paris 6 et CNRS Observatoire Océanologique, 66650 Banyuls-sur-Mer, France.

${ }^{\mathrm{d}}$ Université de Perpignan Via Domitia, Centre de Formation et de Recherche sur les Environnements Méditerranéens, UMR 5110, 66860 Perpignan, France.

${ }^{\text {e }}$ Centre de Formation et de Recherche sur les Environnements Méditerranéens (CEFREM), CNRS, UMR 51110, 66860, Perpignan, France.

*Corresponding author: Florence Vouvé, Université de Perpignan Via Domitia, BiocapteursAnalyses-Environnement, 66860 Perpignan, France

Phone/Fax: (+) 33468662082

E-mail address: vouve@ univ-perp.fr

\section{Acknowledgements}

This study has been partially founded by Hubert Curien Tassili Partnership Program (FranceAlgeria) $\mathrm{N}^{\circ} 15 \mathrm{MDU} 937$. The authors would like to thank the Departmental Council of Pyrénées-Orientales (France) for providing financial support through the Departmental Fund of External Cooperation (France). They gratefully acknowledge the contribution of Algerian Ministry of High Education and Scientific Research through a Doctoral grant from the Outstanding National Program (PNE). 


\begin{abstract}
Cheliff river is the most important permanent river of North-West Algeria which plays an essential role for irrigation and drinking water supply, but suffers from high anthropogenic pressure. Multi-dimensional and multi-factorial aspects of water pollution in Cheliff river and its tributary Mina river were evidenced during two contrasted climatic seasons. Urban discharges were identified as a major source of water organic pollution. The inputs of untreated sewages were characterized by maximum concentrations of tryptophan-like (5.7 $\mu$ mol. $\left.1^{-1}\right)$ and tyrosine-like $\left(9.8 \mu \mathrm{mol}^{-1^{-1}}\right)$ compounds during dry period, confirming these amino acids as fingerprints of untreated urban discharges. The synchronous monitoring and assessment of physicochemical parameters, fluorescent organic compounds and metallic elements of Cheliff river waters highlighted its global contamination, mainly in its downstream part.

Cheliff river was mainly affected by organic pollution with maximum COD (1536 mg O and $\mathrm{BOD}_{5}\left(12 \mathrm{mg} \mathrm{O}_{2} \cdot \mathrm{l}^{-1}\right)$ during wet period, and by metallic contamination with maximum $\mathrm{Fe}$ $\left(287 \pm 4.4 \mu \mathrm{g} . \mathrm{l}^{-1}\right)$ and $\mathrm{Al}\left(422.4 \pm 9.4 \mu \mathrm{g} . \mathrm{l}^{-1}\right)$ during dry period, exceeding the guideline limits. This chronic contamination was related to untreated domestic sewages, agricultural effluents and technical landfill center discharges in this area. Diffuse pollutions were also evidenced, which made the identification of different contamination sources complicated.

Mina river was mostly affected by non-treated domestic sewages with maximum COD

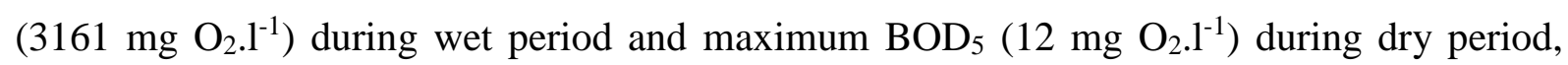
exceeding the guideline limits. The correlation $\mathrm{Li} / \mathrm{Sr}$ showed the contribution of natural influence from saline soils of Mina valley, particularly during dry period.
\end{abstract}

Keywords: Cheliff river, physicochemical parameters, organic compounds, metallic elements, water quality. 


\section{Introduction}

Freshwater ecosystems (lakes, ponds and rivers) are considered one of the most important natural resources for preserving the living organisms of the biosphere. These ecosystems cover only $0.2 \%$ of Earth surface, representing a very small portion compared to the marine and terrestrial habitats (Singh et al. 2010). Besides, natural freshwater is also a fundamental element of many economic sectors including agriculture, industry, livestock production, hydropower generation, etc...(Effendi 2016). Continuous growing of global population increases obviously the demand of freshwater, while this resource tends to diminish due to global climate change. As a result, many people around the World, mainly in Africa, face an increasing risk of water shortages that are expected to cause thousands deaths every year and drives increased climate migration. Recent studies of United Nations, have predicted that about 1.8 billion people will face absolute water scarcity by 2025 (Naimi AitAoudia and Berezowska-Azzag 2016).

Indeed, water resource is strongly affected by anthropogenic activities (industry, agriculture) as well as by the rapid urbanization. Many freshwaters have been shown to be contaminated by different pollutants including organic, inorganic and biological elements (Yan et al. 2016). It is worth noting that water pollutions are the origin of many serious problems to both environment and human worldwide. The increase of deaths and diseases due to water pollution has prompted many scientists to focus their studies on water quality (Cruz et al. 2019; Koukal et al. 2004; Perrin et al. 2014; Salam et al. 2019; Strady et al. 2017).

An important parameter to be considered for water quality evaluation is organic matter, which is ubiquitous in all aquatic systems. This organic matter can be of autochthonous origin due to microbial activity or algal productivity, or allochthonous origin, as a consequence of soil leaching (Winter et al. 2007). However, human activities can affect the organic matter fraction that is present in natural waters, which usually lead to a modification of their concentration and composition (Carstea et al. 2009). The organic matter in water under urban influence is generally analyzed and characterized by fluorescence spectrometry (Baker et al. 2003). Generally, the principal fluorescent components observed in rivers and wastewaters are ascribed to humic substances, including humic and fulvic acids (Baker and Spencer 2004; Hammou 2012). They are also related to fluorescent amino acids that correspond to tryptophan-like, tyrosine-like and phenylalanine-like compounds (Yu et al. 2015). In the case of waters contaminated by urban sewages, the aromatic peptides and their decomposition products can emit a high fluorescence (Carstea et al. 2009). Particularly, tryptophan-like and 
tyrosine-like sewages tracers are used to follow the impact of domestic discharges into river courses (Baker 2001; Osburn et al. 2012).

Algeria is classified by the United Nations Organization as a semi-arid country affected by a water crisis, which facing a serious water shortage with a natural water supply below 500 cubic meters per capita per year (Naimi Ait-Aoudia and Berezowska-Azzag 2016). Moreover, the quality of water in Algeria is considerably altered in the recent years by a demographic growth from 11 million in 1960 to nearly 40 million inhabitants in 2015 (World databank 2017) and also by the industrial expansion.

The present work is focused on the greatest permanent river of Algeria, Cheliff river. This river is an essential water resource for drinking water and irrigation but it suffers from high anthropogenic pressure due to the increasing population density. In this area, the population rose from 5221800 inhabitants in 2008 to 8596527 inhabitants in 2012, producing a volume of domestic wastewater of $637109 \mathrm{~m}^{3} \cdot \mathrm{d}^{-1}$. The region hosts 228 industrial activity units and is also an important agricultural area (Watershed Agency Cheliff-Zahrez 2017). Wastewaters resulting from all these activities are unfortunately released into the natural aquatic environment without any treatment, leading to environmental damages (Belhadj et al. 2006). Up to now, very few studies have been carried on the pollution of Cheliff river, focusing on physicochemical analysis of water compartment (Benson-Evans et al. 2006) and assessment of heavy metals in the superficial sediment (Belhadj et al. 2006). The present work was carried out within the framework of the project Hubert Curien Tassili Partnership Program (France- Algeria) entitled "Contribution to the improvement of environmental quality of the Cheliff river (Algeria)". The aim of this study was thus to assess the impact of urban, agricultural and industrial wastewaters on Cheliff river and its main tributary Mina river. Monitoring and assessment of waters quality were realized by analyzing organic components including fluorescent substances and mineral components including metals in river waters and also directly in identified untreated urban discharges. Two snapshot campaigns were performed along the river and its main tributary during two contrasted climatic periods (wet and dry seasons). Moreover a statistical study was carried out to highlight the potential relations between different pollution indicators.

\section{Materials and methods}

\subsection{Study area}

Cheliff river is a $750 \mathrm{~km}$-long river located in the North-West of Algeria, which drains a watershed of $43.750 \mathrm{~km}^{2}$ (Belhadj et al. 2006). This river has its source in the 
Saharan Atlas, near Aflou in the mountains of Jebel Amour. As it is illustrated in Figure 1, the river mouth on the Mediterranean sea is located about $15 \mathrm{~km}$ from the city of Mostaganem. In this area, the Mina river is the main tributary (135 km-long) of the Cheliff river. The Cheliff and Mina rivers are considered as important water resources for irrigation and drinking waters (Benson-Evans et al. 2006).

The climate of the region is semi-arid with two contrasted climatic periods: wet period characterized by an annual rainfall ranging from 250 to $300 \mathrm{~mm}$ between October and March and a dry period with high temperatures up to $40^{\circ} \mathrm{C}$ in august (Tutiempo Network 2018).

According to previous pedological studies (Boulaine and Bellon 1955; Douaoui et al. 2001), the soils of this region are limey with clay texture. These soils exhibit also distinct levels of sodicity $(\mathrm{Na}, \mathrm{Mg}$ ) in local saline depressions named Sebkha, which can be overflowed during the wet season (Douaoui et al. 2006). The lower Cheliff and Mina plain are among the most important Algerian agricultural regions (Watershed Agency Cheliff-Zahrez 2017) with quite annual diversified crops (citrus orchards, olive trees, melon, watermelon, artichokes and cereals) which are however affected by high soil salinity (Douaoui et al. 2006).

\subsection{Monitoring and sampling site}

The sampling points of water were chosen on the Mina and Cheliff rivers (Fig. 1):

(i) Mina river crosses the town of Relizane, a large agglomeration with a population of 17,832 inhabitants generating a volume of wastewater of $3,351 \mathrm{~m}^{3}$ per day (National Sanitation Office of Relizane (Algeria) 2014).

Sampling stations are located inside the raw urban discharge (M2 station), upstream of the urban discharge (M1station) and downstream of urban discharge (M3 station).

(ii) The impact evaluation of Mina inputs inside the Cheliff river requires the sampling upstream of the confluence ( $\mathrm{C} 1$ station) and downstream of the confluence (C2 station).

(iii) Cheliff river crosses an agglomeration called Sour, with an estimated 4,475 population (2013) rejecting approximately $430 \mathrm{~m}^{3}$ of urban wastewater per day (Hydraulic Steering of Mostaganem (Algeria) 2013). The sampling was realized inside (C4 station), upstream (C3 station) and downstream (C5 station) of urban discharges. These stations are located near a technical landfill center.

To estimate the quality of Cheliff water inputs into the Mediterranean sea, a last sampling site (station C6) was chosen $300 \mathrm{~m}$ upstream from the river mouth close to a desalination plant.

To study the impact of urban discharges to both rivers, water samples were collected during the two characteristic climatic periods: in February-March 2015 (wet period) and August 2015 (dry period). The influence of Mina inputs for the Cheliff river was evaluated in a 
second time with water sampling at the stations C1, C2 during the wet period on February 2016. During the dry period, the Cheliff river was dried in $\mathrm{C} 1$ and $\mathrm{C} 2$ stations, which made the sampling impossible. The flow data were not available for the studied period (2015-2016).

\subsection{Samples preparation}

Water samples were taken in 1.5 liter polyethylene bottles cleaned with $2 \%$ nitric acid. At each station, three bottles were sampled in order to obtain a composite sample after mixing. In the laboratory, the composite samples were divided into three aliquots: the first one for physicochemical analyses was filtered through cellulose filter (alpha-cellulose Grade 589/3). The second part, intended to metal analyses, was filtered through cellulose nitrate filters (porosity $0.45 \mu \mathrm{m}$ ) and acidified with $2 \%$ of concentrated nitric acid $65 \%$ of trace metal grade. The last part was intended for fluorescence analyses after filtration with cellulose nitrate filters (porosity $0.45 \mu \mathrm{m}$ ) and addition of $1 \%$ of sodium azide $(1 \mathrm{M})$ to prevent microbial activity. All samples were stored in the dark at $4^{\circ} \mathrm{C}$ before analysis.

\subsection{Analysis}

\subsubsection{Physicochemical analyses}

At each sampling station: $\mathrm{pH}$, temperature and conductivity were measured in situ using adequate electrodes (Consort C562). The instrument was calibrated with standard solution before use. The total suspended materials (TSM) were used to measure the total particulate matter in waters. TSM were determined according to the normalized method NF T90-105 (AFNOR 1999). The organic pollution was evaluated through the determination of Chemical Oxygen Demand (COD), according to the normalized method NF T90-101 (AFNOR 1999) and Biochemical Oxygen Demand (BOD 5 ), according to the normalized method NF T90-103 (AFNOR 1999) using OxiTop ${ }^{\mathrm{TM}}$ bottles. Mineral components determinations were carried out using an Optizen 3220 Spectrophotometer for sulphates $\left(\mathrm{SO}_{4}{ }^{2-}\right)$, nitrites $\left(\mathrm{NO}_{2}^{-}\right)$, nitrates $\left(\mathrm{NO}_{3}{ }^{-}\right)$according to respective normalized methods $\mathrm{NF}$ T90040, NF T90-013 and NF T90-012 (AFNOR 1999) based on calibration curves. Chloride $\left(\mathrm{Cl}^{-}\right)$ was measured according to the normalized method NF T90-014 (AFNOR 1999). For each analyze, a blank (purified water) was carried out in the same analytical conditions as samples. All samples were analyzed in triplicate in order to obtain reliable results.

\subsubsection{Metals analyses}

Metallic elements ( $\mathrm{Cu}, \mathrm{Zn}, \mathrm{Al}, \mathrm{Fe}, \mathrm{Mn}, \mathrm{Cd}, \mathrm{Pb}, \mathrm{As}, \mathrm{Ni}, \mathrm{Cr}, \mathrm{Sr}, \mathrm{Li})$ were analyzed by Inductively Coupled Plasma-Mass Spectrometry (ICP-MS Agilent 7700X). The instrument realized 300 measurement replicates for each sample. The detection limits of instrument for each metal are indicated in Table 1. 
The certified reference material 1640a from the NIST (National Institute of Standards and Technology: https://www.nist.gov) was used in order to check the quality of the analysis. The recovery percentages relative to the reference material 1640a are given in Table 1. They varied from 81 to $105 \%$ depending on the element.

\subsubsection{Fluorescent organic matter analyses}

The fluorescent dissolved organic matter (DOM) was measured by three-dimensional Fluorescence Excitation-Emission Matrix (FEEM) technology using Safas-flx spectrofluorimeter. All samples were first analyzed in UV-Visible absorption spectroscopy to verify that the absorbance of each sample at $\lambda=254 \mathrm{~nm}$ is below 0.3 (Ohno 2002). If necessary, dilutions were carried out to correct samples for inner-filtering before fluorescence measurements. Excitation and emission slit widths were set to $10 \mathrm{~nm}$ bandpass and photomultiplier voltage to $800 \mathrm{~V}$. Excitation wavelengths (Ex) varied from 200 to $500 \mathrm{~nm}$ every $10 \mathrm{~nm}$ intervals and emission wavelengths $(\mathrm{Em})$ varied from 210 to $800 \mathrm{~nm}$ at $1 \mathrm{~nm}$ intervals. The fluorescence intensity was measured in arbitrary units (a.u.). The blank (purified water) was analyzed in the same conditions as the samples. FEEM of blank (purified water) acquired was subtracted from FEEMs of samples before to be modeled with PARAFAC (Parallel Factor Analysis) using the DOMFluor toolbox for Matlab to separate the fluorescent components (Stedmon and Bro 2008). The correction of Raman and Rayleigh diffusions was applied for all fluorescence spectra.

The number of components was tested between 3 and 10 components. The best model was determined from the shape of the component's spectra and the value of Core Consistency Diagnostic (CORCONDIA), which must be greater than $60 \%$ to validate the model (Bro and Kiers 2003).

\subsection{Statistical analysis}

Principal component analysis (PCA) was performed to study the potential correlations between physicochemical, fluorescent organic, mineral and metallic parameters. PCA was applied to the whole spatio-temporal data ( 9 stations, 2 periods) using following parameters: $\mathrm{COD}, \mathrm{BOD}_{5}, \mathrm{Cl}^{-}, \mathrm{SO}_{4}{ }^{2-}, \mathrm{NO}_{2}^{-}, \mathrm{NO}_{3}^{-}$, TSM, tryptophan, tyrosine, $\mathrm{Cu}, \mathrm{Zn}, \mathrm{Fe}, \mathrm{Al}, \mathrm{Mn}, \mathrm{Cr}, \mathrm{Ni}$, $\mathrm{As}, \mathrm{Cd}, \mathrm{Pb}, \mathrm{Li}$ and $\mathrm{Sr}$. The analysis was conducted using Addinsoft XLSTAT software.

\section{Results and discussion}

This study presents for the first time an integrative dataset concerning the urban discharges and the water quality characteristics of Cheliff and Mina rivers.

The results of the physicochemical and metallic composition of urban discharges will be first discussed before to present the spatial variations of those parameters in both rivers. The 
fluorescence results will be exposed in the same way later to characterize the dissolved organic matter (DOM).

\subsection{Characterization of untreated urban discharges (M2 and C4)}

\subsubsection{Physicochemical parameters}

M2 and C4 represent two identified urban discharges rejected without any treatment into Mina and Cheliff rivers, respectively. Figure 2 shows the main physicochemical parameters measured for these samples collected during dry and wet periods.

The M2 station was characterized by high chloride content $\left(887.5 \pm 5.0 \mathrm{mg} . \mathrm{l}^{-1}\right)$ and elevated COD value (979 $\left.\mathrm{mg} \mathrm{O}_{2} . \mathrm{l}^{-1}\right)$ during wet period, while high concentration of TSM $(960.0 \pm 1.5$ mg..$\left.^{-1}\right)$ was observed during dry period. Nitrites $\left(0.50 \pm 0.09 \mathrm{mg} . \mathrm{l}^{-1}\right)$ and sulphates $(35.8 \pm 2.8$ mg. $\mathrm{l}^{-1}$ ) had similar concentrations during both periods. The $\mathrm{C} 4$ station was characterized by high values of conductivity $\left(8.6 \pm 0.2 \mathrm{mS} . \mathrm{cm}^{-1}\right)$ during wet period and high concentrations of COD (1032 $\left.\mathrm{mg} \mathrm{O}_{2} \cdot \mathrm{l}^{-1}\right)$ and nitrites $\left(0.90 \pm 0.09 \mathrm{mg} . \mathrm{l}^{-1}\right)$ during dry period.

These results were compared with the Algerian guidelines for treated wastewater used for irrigation (Algerian guidelines 2012). The available parameters in these guidelines were conductivity, chloride and COD with permitted values $30 \mathrm{mS} . \mathrm{cm}^{-1}, 10 \mathrm{mg} . \mathrm{l}^{-1}$ and $90 \mathrm{mg} \mathrm{O} \cdot \mathrm{O}^{-1}$, respectively. Despite the values of conductivity were far below the allowed limit, it was shown that chloride and COD largely exceeded the permitted limits, demonstrating that untreated urban discharges contribute to the global contamination of the rivers.

\subsubsection{Metallic composition}

The concentrations of metals $(\mathrm{Cu}, \mathrm{Zn}, \mathrm{Fe}, \mathrm{Al}, \mathrm{Mn}, \mathrm{Cr}, \mathrm{Ni}, \mathrm{As}, \mathrm{Cd}$ and $\mathrm{Pb})$ are presented in Figure 3. The samples M2 and C4 (urban sewages) were compared to the Algerian guidelines for wastewater treated for irrigation (Algerian guidelines 2012). These guidelines fixed the following limits for metallic elements: $\mathrm{Cu}\left(5 \mathrm{mg} . \mathrm{l}^{-1}\right), \mathrm{Fe}\left(20 \mathrm{mg} . \mathrm{l}^{-1}\right), \mathrm{Cr}(1$ mg. $\left.\mathrm{l}^{-1}\right)$, Ni $\left(2 \mathrm{mg} \cdot \mathrm{l}^{-1}\right)$, As $\left(2 \mathrm{mg} \cdot \mathrm{l}^{-1}\right), \mathrm{Cd}\left(0.05 \mathrm{mg} . \mathrm{l}^{-1}\right), \mathrm{Pb}\left(10 \mathrm{mg} \cdot \mathrm{l}^{-1}\right)$. It was shown that M2 and $\mathrm{C} 4$ samples were characterized by weak concentrations of metals in both seasons, in the $\mu \mathrm{g} . \mathrm{l}^{-1}$ order, much lower than the permitted limits (in the mg. $\mathrm{l}^{-1}$ level).

M2 station was characterized by quite values of $\mathrm{Cu}, \mathrm{Zn}, \mathrm{Ni}, \mathrm{As}, \mathrm{Cd}$ and $\mathrm{Pb}$. Except for $\mathrm{Cd}$, the concentrations of these metals increased during the dry season up to maximal values of $6.1 \pm 0.2 \mu \mathrm{g} .1^{-1}$ for $\mathrm{Cu}, 5.33 \pm 0.04 \mu \mathrm{g} .1^{-1}$ for As and $7.5 \pm 0.2 \mu \mathrm{g} .1^{-1}$ for $\mathrm{Ni}$.

$\mathrm{C} 4$ station showed predominant concentrations of $\mathrm{Cu}, \mathrm{Fe}, \mathrm{Ni}, \mathrm{As}$ and $\mathrm{Pb}$ during dry season with a maximum for $\mathrm{Fe}\left(375.4 \pm 7.9 \mu \mathrm{g} . \mathrm{l}^{-1}\right)$. Only $\mathrm{Cr}$ and $\mathrm{Cd}$ concentrations increased during wet period up to $119.8 \pm 0.3 \mu \mathrm{g} . \mathrm{l}^{-1}$ (maximum) for $\mathrm{Cr}$ and $0.150 \pm 0.007 \mu \mathrm{g} . \mathrm{l}^{-1}$ for $\mathrm{Cd}$. In this region, the network collects sewages from urban and peripheral area which are mixed in a 
single pipe system, so that the presence of metals in urban wastewaters may have different possible origins including domestic, industrial, farming and craft activities (National Sanitation Office of Relizane (Algeria) 2014). M2 sampling station is probably affected by agricultural activities around the area with the extensive and punctual use of agrochemicals (pesticides and fertilizers) along the seasons depending on the type of crop that can explain the presence of metals $(\mathrm{Cu}, \mathrm{Ni}, \mathrm{As}, \mathrm{Cd}$ and $\mathrm{Pb})$ at notable levels. On the other hand, $\mathrm{C} 4$ is located close to an urban area (Sour city) where household tanneries reject high $\mathrm{Cr}$ concentrations (Koukal et al. 2004) mixed with urban discharge metallic concentrations. However, farming activities are also intense around this area and may be responsible for important $\mathrm{Fe}$ and $\mathrm{Cd}$ release from fertilizers (Bu et al. 2017).

\subsection{Spatio-temporal variations in watercourses (M1, M3, C1, C2, C3, C5, C6)}

\subsubsection{Physicochemical parameters}

Seasonal and spatial variations of physicochemical parameters measured in Mina and Cheliff rivers are shown in Figure 2. Water quality characteristics were evaluated by comparison to Algerian guidelines concerning surface waters intended for human consumption, when available (Algerian guidelines 2011). During dry season, values at C1 and C2 were not available as the river was completely dried.

During wet period the $\mathrm{pH}$ of waters varied between 6.4 at $\mathrm{M} 1$ to 8.6 at $\mathrm{C} 1$, while at dry period the values recorded varied from 7.5 at $\mathrm{C} 3$ to 8.3 at $\mathrm{C} 6$. These $\mathrm{pH}$ values were in agreement with those permitted in the guidelines (6.5-8.5).

Water temperature ranged from $12.3^{\circ} \mathrm{C}$ at $\mathrm{C} 6$ to $26.1^{\circ} \mathrm{C}$ at $\mathrm{C} 3$ in wet period and from $27.2^{\circ} \mathrm{C}$ at $\mathrm{M} 1$ to $29.3^{\circ} \mathrm{C}$ at $\mathrm{C} 6$ during dry period.

The conductivity is strongly related to the presence of major species $\left(\mathrm{Ca}^{2+}, \mathrm{Mg}^{2+}, \mathrm{K}^{+}, \mathrm{Na}^{+}\right.$, $\mathrm{HCO}_{3}{ }^{-}, \mathrm{SO}_{4}{ }^{2-}, \mathrm{Cl}^{-}, \ldots$ ) in water (Çadraku et al. 2016). Conductivity exceeded the permissible

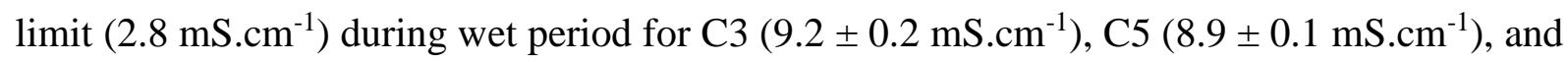
especially C6 $\left(80.0 \pm 1.3 \mathrm{mS} . \mathrm{cm}^{-1}\right)$. These stations are located downstream of the confluence. The high conductivities at $\mathrm{C} 3$ and $\mathrm{C} 5$ might be related to the $12 \mathrm{~mm}$ rainfall that was measured 2 days before sampling (Tutiempo Network 2018), which led to saline soil leaching and re-solubilisation of magnesium and calcium in river water (Daoud et al.1993). Inputs from technical landfill center could also reach the river after overflowing from retention basins and contribute to high conductivities. At C6, the maximum of conductivity reflected the marine influence. 
The presence of high concentrations of chloride in the different samples collected could be attributed to the saline nature of soils within the study area (Douaoui et al. 2006). On Mina river, chloride concentrations were slightly higher than Algerian guideline limits $\left(600 \mathrm{mg} . \mathrm{l}^{-1}\right)$ with averages concentrations of $666 \pm 35 \mathrm{mg} . \mathrm{l}^{-1}$ during wet period and $797 \pm 16 \mathrm{mg} . \mathrm{l}^{-1}$ during dry period. Along the Cheliff river, the C3, C5 and C6 stations displayed the highest chloride concentrations during dry period $\left(1273.0 \pm 50.2,1287.0 \pm 50.2\right.$ and $887.0 \pm 30.7 \mathrm{mg} . \mathrm{l}^{-1}$, respectively). The high temperatures (around $30^{\circ} \mathrm{C}$ ) observed during this period may be responsible for increased evaporation, thus leading to an increase of chloride concentrations. During wet period, C1 and C2 stations presented the lowest recorded values (respectively $420.0 \pm 7.5$ and $166.0 \pm 2.0 \mathrm{mg} . \mathrm{l}^{-1}$ ) which can be explained by the dilution effect due to rainfalls.

The COD values during wet period ranged from $29 \mathrm{mg} \mathrm{O}_{2} \cdot \mathrm{l}^{-1}$ at $\mathrm{C} 2$ station to $3161 \mathrm{mg} \mathrm{O} 2 . \mathrm{l}^{-1}$ at M1 station. The values recorded at stations M1 (3161 mg O $\left.2.1^{-1}\right)$, M3 (1056 mg O $\left.2.1^{-1}\right)$, C5

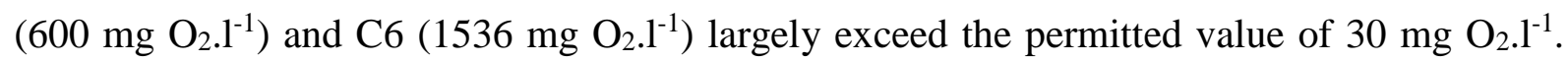
During the dry period, lower values of COD were measured, with maximum at C3 and C5 (72 $\mathrm{mg} \mathrm{O}_{2} \cdot \mathrm{l}^{-1}$ ). On the other hand, $\mathrm{BOD}_{5}$ was shown to be very weak during wet period with average value of $1.8 \mathrm{mg} \mathrm{O}_{2} .1^{-1}$, except at $\mathrm{C} 1\left(12 \mathrm{mg} \mathrm{O}_{2} .1^{-1}\right)$ where $\mathrm{BOD}_{5}$ exceeded the recommended value of $7 \mathrm{mg} \mathrm{O}_{2} \cdot \mathrm{l}^{-1}$. During dry period, $\mathrm{BOD}_{5}$ exceeded this limit in Mina river to reach $9.3 \mathrm{mg} \mathrm{O}_{2} .1^{-1}$ at $\mathrm{M} 1$, and $12 \mathrm{mg} \mathrm{O}_{2} .1^{-1}$ at $\mathrm{M} 3$, however $\mathrm{BOD}_{5}$ was below the limit in Cheliff river with similar values measured in $\mathrm{C} 3, \mathrm{C} 5$, and C6 (average of $3.6 \mathrm{mg} \mathrm{O}_{2} \cdot \mathrm{l}^{-1}$ ). Consequently, the mean value of $\mathrm{BOD}_{5} / \mathrm{COD}$ ratio (0.07) for all samples during both periods was less than 0.3. Such ratio indicated that the biodegradability of pollutants was very low (Yu et al. 2015)in the Cheliff and Mina rivers.

The concentrations of nitrites, nitrates and sulphates were below the guidelines limits $(0.5$ mg. $\mathrm{l}^{-1}, 50 \mathrm{mg} . \mathrm{l}^{-1}$ and $400 \mathrm{mg} \cdot \mathrm{l}^{-1}$ respectively) in all stations. Nitrites concentrations ranged from $0.10 \pm 0.01 \mathrm{mg} . \mathrm{l}^{-1}$ at $\mathrm{C} 2$ to $0.30 \pm 0.01 \mathrm{mg} . \mathrm{l}^{-1}$ at $\mathrm{C} 1$ and $\mathrm{C} 6$ during wet period and from $0.30 \pm 0.01 \mathrm{mg} . \mathrm{l}^{-1}$ at $\mathrm{M} 1$ to $0.50 \pm 0.02 \mathrm{mg} . \mathrm{l}^{-1}$ at C5 during dry period. The nitrates concentrations varied from $0.50 \pm 0.01 \mathrm{mg} . \mathrm{l}^{-1}$ at $\mathrm{C} 2$ to $3.8 \pm 0.3 \mathrm{mg} . \mathrm{l}^{-1}$ at $\mathrm{C} 3$ during wet period and from $0.80 \pm 0.08 \mathrm{mg} . \mathrm{l}^{-1}$ at $\mathrm{C} 6$ to $2.0 \pm 0.2 \mathrm{mg} . \mathrm{l}^{-1}$ at $\mathrm{C} 3$ during dry period. The sulphates concentrations ranged from $32.2 \pm 1.5 \mathrm{mg} . \mathrm{l}^{-1}$ at $\mathrm{M} 1$ to $78.6 \pm 3.0 \mathrm{mg} . \mathrm{l}^{-1}$ at $\mathrm{C} 1$ during wet period and from $33.1 \pm 1.0 \mathrm{mg} . \mathrm{l}^{-1}$ at $\mathrm{C} 6$ to $81.3 \pm 1.4 \mathrm{mg} . \mathrm{l}^{-1}$ at M1 during dry period.

There is no guideline for total suspended matter (TSM) to evaluate water quality. These values varied from $30 \pm 13 \mathrm{mg} . \mathrm{l}^{-1}$ at $\mathrm{C} 1$ to $440 \pm 1 \mathrm{mg} . \mathrm{l}^{-1}$ at $\mathrm{C} 5$ during wet period and from 57 $\pm 1 \mathrm{mg} \cdot \mathrm{l}^{-1}$ at C6 to $645 \pm 1 \mathrm{mg} . \mathrm{l}^{-1}$ at C5 during dry period. TSM often transported the different 
contaminants adsorbed on particles in the water column. TSM can be originated from the anthropogenic activities (agricultural and urban sewages) (Houhou et al. 2010) and/or natural soil leaching. During dry period, evaporation of water and development of algal boom can induce an increase of TSM concentrations when the water flow was weak.

Some of the physicochemical parameters measured in the present study were compared with those obtained in previous studies concerning Cheliff river (Benson-Evans et al. 2006) and other rivers located in Morocco (Koukal et al. 2004) and Egypt (Elewa 2010) (Table 2). The previous study on Cheliff and Mina rivers showed approximately the same level of chlorides but lower values of $\mathrm{BOD}_{5}$. In Morocco, the study of Sebou river indicated lower values of chloride and $\mathrm{BOD}_{5}$ but higher values of sulphates compared to the present results. Another study carried out on Nile river in Egypt reported levels of chlorides, $\mathrm{BOD}_{5}$ and sulphates much lower than those measured in this study. These comparisons showed that there was an increase of organic inputs $\left(\mathrm{BOD}_{5}\right)$ in the Cheliff river between previous and present studies. At this moment the Cheliff river was characterized by higher concentrations of chlorides, $\mathrm{BOD}_{5}$, sulphates compared to Nil river and of chlorides, $\mathrm{BOD}_{5}$ compared to Sebou river. However the concentrations of sulphates were lower than those found in Sebou river.

\subsubsection{Metallic composition}

The spatio-temporal variations of metals $(\mathrm{Cu}, \mathrm{Zn}, \mathrm{Fe}, \mathrm{Al}, \mathrm{Mn}, \mathrm{Cr}, \mathrm{Ni}, \mathrm{As}, \mathrm{Cd}$ and $\mathrm{Pb}$ ) in river waters are presented in Figure 3. The results were compared to the Algerian guidelines of surface waters intended for human consumption (Algerian guidelines 2011). French guidelines were used only when the Algerian guidelines were not available (French guidelines 2013).

During dry period, the metallic contamination in Cheliff river results in high concentrations of Fe at C3 $\left(287.0 \pm 4.4 \mu \mathrm{g} .1^{-1}\right)$ and C5 (255.6 $\left.\pm 1.2 \mu \mathrm{g} . \mathrm{l}^{-1}\right)$, and also of Al at C5 (422.4 \pm 9.4 $\left.\mu \mathrm{g} .1^{-1}\right)$, exceeding the recommended values. At $\mathrm{C} 3$ the concentration of $\mathrm{Al}$ was also significant $\left(183.3 \pm 2.1 \mu \mathrm{g} .1^{-1}\right)$, but below the limit. Regarding the other metals, the concentrations were always below the guidelines. However, two stations (C3 and C5) were characterized by notable concentrations of $\mathrm{Zn}, \mathrm{Mn}, \mathrm{As}, \mathrm{Cd}, \mathrm{Pb}$ and only station (C5) for $\mathrm{Cu}$. During these samplings, the river flow was very weak, which may explain the obtained high metallic concentrations. C3 and C5 stations were also affected by crop treatments carried out over the seasons (crop rotation) and technical landfill center effluents, which can explain enhanced concentrations of $\mathrm{Zn}, \mathrm{Al}$, As, $\mathrm{Cd}$, $\mathrm{Pb}$. Moreover, the increase of $\mathrm{Zn}$ concentrations in the river might be related to the farming activities, as well as domestic effluents (Mendiguchía et al. 2007; $\mathrm{Bu}$ et al. 2017). High concentrations of Fe and Mn may be explained by colloid 
destabilization and reduction of sedimentary iron/manganese oxyhydroxides in hypoxic conditions ( $\mathrm{Bu}$ et al. 2017) especially during dry period. During wet period, only C2 presented significant concentrations of $\mathrm{Zn}, \mathrm{Ni}, \mathrm{Cd}$ and $\mathrm{Pb}$. In this case, their potential sources were uncertain, one hypothesis may be the leaching from uncontrolled discharges which could not be identified in this work.

Mina river (M1 and M3) did not reveal specific metallic contamination. The concentrations measured in both seasons were weak and far below the guidelines limits. Despite this, Mina river was characterized by predominant concentrations of $\mathrm{Cu}, \mathrm{Zn}, \mathrm{Ni}, \mathrm{As}, \mathrm{Cd}$ and $\mathrm{Pb}$, mostly during wet period. The presence of these elements may be related to farming activities and extensive application of fertilizers and pesticides as zinc arsenate $\left(\mathrm{Zn}_{3}\left(\mathrm{AsO}_{4}\right)_{2}\right)$ and lead arsenate $\left(\mathrm{Pb}_{3}\left(\mathrm{AsO}_{4}\right)_{2}\right)$ (Zhaoyong et al. 2015). The presence of metals as dissolved elements was probably due to leaching of soils after rainfalls.

Mina river was affected by identified urban discharge (M2) enriched in $\mathrm{Cu}, \mathrm{Zn}, \mathrm{Ni}, \mathrm{As}, \mathrm{Cd}$ and $\mathrm{Pb}$ which appeared more diluted at $\mathrm{M} 3$ station located $0.2 \mathrm{~km}$ downstream (Fig. 1). On the opposite, Cheliff river was moderately affected by identified urban discharges (C4) with the higher metallic concentrations in $\mathrm{C} 5$ station $(2.5 \mathrm{~km}$ downstream) except for $\mathrm{Fe}$ and $\mathrm{Ni}$. Besides, Cheliff inputs influenced the water quality of coastal zone as observed in the C6 station (mouth of Cheliff river). High concentrations of metals ( $\mathrm{Zn}, \mathrm{Fe}, \mathrm{Al}, \mathrm{As}, \mathrm{Cd}, \mathrm{Pb}$ ) were mostly measured during dry period, mainly due to enhanced evaporation of waters at temperatures around $30^{\circ} \mathrm{C}$.

Compared to other rivers like Moulouya in Morocco (Bouabdli et al. 2005), Guadalquivir in Spain (Mendiguchía et al. 2007), Nile in Egypt (Elewa 2010) and Rhône in France (Ollivier et al. 2011), Cheliff river presented higher concentrations (up to 14-fold) of $\mathrm{Cu}, \mathrm{Zn}, \mathrm{Mn}, \mathrm{Ni}, \mathrm{Cd}$ and $\mathrm{Pb}$ (Table 3). Higher levels of $\mathrm{Cd}$ and $\mathrm{Pb}$ were found only in Nile river, with concentrations 7-fold and 3-fold higher for $\mathrm{Cd}$ and $\mathrm{Pb}$, respectively. When compared to others rivers the Cheliff river was globally characterized by a highe pollution by metallic elements $(\mathrm{Cu}, \mathrm{Zn}, \mathrm{Mn}, \mathrm{Ni}, \mathrm{Cd}$ and $\mathrm{Pb})$.

\subsection{Saline soils fingerprints through $\mathrm{Li} / \mathrm{Sr}$ abundances}

According to the soil map of study area ( (Boulaine and Bellon 1955), this region was affected by the presence of saline soils in the watershed. The combination of the two elements $\mathrm{Li} / \mathrm{Sr}$ was strongly used to identify the areas most affected by the problem of salinity (Laiche 2017). In order to study the natural influence of these saline soils on the waters of Cheliff and Mina rivers, we have drawn the $\mathrm{Li} / \mathrm{Sr}$ concentrations during wet and dry periods. 
Figure 4 shows the relationships between $\mathrm{Li}$ and $\mathrm{Sr}$ taking into account all sampling stations. The correlations $\mathrm{Li} / \mathrm{Sr}$ were established on Mina river stations $\left(\mathrm{R}^{2}=0.919\right)$ and Cheliff river stations $\left(\mathrm{R}^{2}=0.924\right)$ separately (Fig. 4). Sr was present in abundance in the soils rich on $\mathrm{Ca}^{2+}$ (Laiche 2017), which could be related to the limey composition of the lower Cheliff and Mina watershed soils (Boulaine and Bellon 1955; Douaoui et al. 2001). Particularly, Mina river (M1 and M3) exhibited higher Li concentrations than those measured on the Cheliff river, confirmed by higher slope of the linear regression obtained for Mina river (0.035) compared to Cheliff river (0.017). Higher Li concentrations in Mina river were related to the specific occurrence of Solonchak-type saline soils, which are deemed to contain this element in great abundance (Kabata-Pendias and Szteke 2015).

Seasonal trends were also observed, with highest concentrations of $\mathrm{Sr}$ and $\mathrm{Li}$ found during dry period both in Cheliff (C3 and C5 stations) and Mina rivers (M1 and M3 stations). Evaporation of waters during dry period led to increased concentrations of dissolved elements, it was the key process responsible for high concentrations of $\mathrm{Sr}$ and Li. During the wet period, Sr and Li concentrations were significantly diluted (M1, M3, C3, C5, C1, C2, C6). Their concentration therefore appeared to be controlled mainly by natural processes. However, two stations (C4 and M2) corresponding to urban discharges did not follow this trend and showed very low $\mathrm{Sr}$ and $\mathrm{Li}$ concentrations whatever the considered season. Those effluents were not influenced by the natural processes mentioned above, so that their specific signature with low $\mathrm{Li}$ and $\mathrm{Sr}$ concentrations could be used as a tracer of urban anthropogenic outflow.

\subsection{Characteristics of fluorescent dissolved organic matter (DOM)}

Figure 5 presents FEEM examples typical of DOM in the Cheliff river during two contrasted periods. These FEEMs might characterize the organic matter composition by the excitation/emission wavelengths and fluorescence intensities. Two peaks could be distinguished in the matrices obtained from Cheliff river DOM (Fig. 5). These peaks showed different fluorescence intensities (FI) depending on the station and season. Peak 1 was clearly noticeable at $\mathrm{C} 3$ and $\mathrm{C} 4$ during wet period with FI similar to those of peak 2. For the other FEEMs, peak 2 intensities were higher than those of peak 1, so that the latter appeared as a shoulder. However, FI of peak 1 were similar for both seasons at C3, C4 and C5. The highest FI was observed at $\mathrm{C} 4$ station (urban discharge) especially during dry period, with values of 200 a.u. for peak 2 and 90 u.a. for peak 1. A decreased of FI was logically observed downstream of urban discharge, at C5 station, with FI=15 a.u. and 50 a.u. for peak 2 and FI=6 u.a. to 15 u.a. for peak 1 during wet and dry periods respectively. Both peaks 1 and 2 showed 
higher FI during the low water period. The presence of peak 1 in C3 station (upstream of urban discharge) can be explained by the non-point source pollution of Cheliff river.

The FEEMs obtained for all samples were modeled with PARAFAC application ((Stedmon and Bro 2008), revealing the presence of 6 components with a CORCONDIA of more than 95\%. Fingerprints of 4 components allowed rapidly identifying them as humic substances (Osburn et al. 2012; Yu et al. 2015), while the two other corresponded to tryptophan-like and tyrosine-like amino acids, as confirmed by analysis of pure amino acids. These two amino acids present a special interest as urban pollution markers (Carstea et al. 2009) of Cheliff and Mina rivers.

\subsection{Tryptophan-like and tyrosine-like variations}

The fluorescence intensities of tryptophan-like and tyrosine-like amino acids were converted into concentrations using the calibration curves prepared with pure products. This allowed quantifying the tryptophan-like and tyrosine-like in each water sample during the two characteristic periods (Fig. 6).

\subsubsection{Urban discharges (M2, C4)}

Tryptophan-like and tyrosine-like compounds were detected in M2 and C4 stations during the two contrasted periods (Fig. 6). The highest concentrations of tryptophan-like peptides were detected at M2 station $\left(5.4 \mu \mathrm{mol} . \mathrm{l}^{-1}\right)$ and $\mathrm{C} 4$ station $\left(5.7 \mu \mathrm{mol} . \mathrm{l}^{-1}\right)$ during dry period, and only at $\mathrm{C} 4$ station $\left(4.8 \mu \mathrm{mol}^{-1} \mathrm{l}^{-1}\right)$ during wet period. These concentrations were in the same order of magnitude as those measured in influents from the wastewater treatment plant (WWTP) of a French city of 120000 inhabitants (Perpignan, France: $3.5 \pm 0.4 \mu \mathrm{mol}^{-1^{-1}}$ ) (Hammou 2012).

The highest concentrations of tyrosine-like peptides were detected at $\mathrm{C} 4$ station, with values ranging from $4.8 \mu \mathrm{mol} . \mathrm{l}^{-1}$ (wet period) to $9.8 \mu \mathrm{mol}^{-1}$ (dry period). At M2 station these concentrations were $1.9 \mu \mathrm{mol} . \mathrm{l}^{-1}$ during wet period and reached $5.4 \mu \mathrm{mol} . \mathrm{l}^{-1}$ during dry period.

According to previous studies (Carstea et al. 2009; Vouvé et al. 2009; Hammou 2012), tryptophan-like and tyrosine-like peptides are characteristic of urban wastewaters, especially when found at high concentrations such in M2 and C4 stations. Tyrosine-like compounds have been also described as markers of milk protein in urban wastewaters (Duée et al. 1973). Seasonal variations of tryptophan-like and tyrosine-like concentrations can also be related to microbial activities (Osburn et al. 2012; Stedmon et al. 2008) that are much more intense at dry period. It must be stressed during this period, and also the reduction of discharge flow 
also led to increasing concentrations of dissolved compounds and solid materials (TSM) (Fig. 2).

\subsubsection{Watercourses (C1, C2, M1, M3, C3, C5, C6)}

Figure 6 shows the spatio-temporal variations of tryptophan-like and tyrosine-like compounds along the Cheliff river and its tributary Mina river. The concentrations of tryptophan-like varied from $0.1 \mu \mathrm{mol} . \mathrm{l}^{-1}$ at $\mathrm{M} 1$ station to $0.7 \mu \mathrm{mol} . \mathrm{l}^{-1}$ at $\mathrm{C} 3$ station during wet period and between $0.2 \mu \mathrm{mol} . \mathrm{l}^{-1}$ at M3 station to $1.2 \mu \mathrm{mol} . \mathrm{l}^{-1}$ at C5 station during dry period. The lowest concentrations were measured at $\mathrm{C} 1$ station $\left(0.07 \mu \mathrm{mol} . \mathrm{l}^{-1}\right)$ and $\mathrm{C} 2$ station $(0.06$ $\mu \mathrm{mol} . \mathrm{l}^{-1}$ ) during wet period. At dry season, the concentrations of tryptophan-like compounds in Mina river $\left(0.27 \mu \mathrm{mol} . \mathrm{l}^{-1}\right.$ at M1 to $0.20 \mu \mathrm{mol} . \mathrm{l}^{-1}$ at M3) were similar to those found in Têt river (France) downstream of the Perpignan WWTP (France) (Table 2) (Hammou 2012). However, the concentrations in Cheliff river $\left(1.20 \mu \mathrm{mol}^{-1} \mathrm{l}^{-1}\right.$ at $\mathrm{C} 5$ to $0.98 \mu \mathrm{mol} . \mathrm{l}^{-1}$ at C6) were found to be respectively 5 to 33 times higher than in the Têt river (Table 2) (Hammou 2012). Tryptophan-like fluorescence has been described in many studies as a good indicator of the presence of sewage waters in rivers (Baker et al. 2003; Hudson et al. 2008; Vouvé et al. 2009; Hammou 2012). The presence of this fluorophore in all stations revealed the contamination of Cheliff river and its tributary Mina river by the identified untreated urban discharges (M2 and $\mathrm{C} 4)$, but also by additional uncontrolled urban discharges (C1, C2, C3, C6 and M1). A dilution effect was logically observed in M3 station which is located $0.2 \mathrm{~km}$ downstream from M2 (4\% of residual fluorescence), and in C5 station which is located $2.5 \mathrm{~km}$ downstream from C4 (21\% of residual fluorescence).

On the other hand, low concentrations of tyrosine-like compounds were found in watercourses, ranging from $0.05 \mu \mathrm{mol}^{-1} \mathrm{l}^{-1}$ at $\mathrm{C} 2$ station and $0.7 \mu \mathrm{mol} . \mathrm{l}^{-1}$ at $\mathrm{C} 3$ station during wet period and from $0.05 \mu \mathrm{mol} . \mathrm{l}^{-1}$ at $\mathrm{M} 1$ station to $0.3 \mu \mathrm{mol} . \mathrm{l}^{-1}$ at $\mathrm{C} 3$ station during dry period. According to the study of (Hudson et al. 2008), tyrosine-like compounds in water systems originate from bacterial activity.

\subsection{Statistical analysis}

A Principal Component Analysis (PCA) was performed to study the potential relation between the studied parameters and sampling stations. The results of the PCA (Fig.7) indicated that two principal axes explained $55.72 \%$ of the total variance with the contributions of F1 (33.02\%) and F2 (22.70\%).

In the corresponding chart (F1-F2) (Fig. 7a), along axis F1, variables $\mathrm{Al}, \mathrm{Mn}, \mathrm{Zn}, \mathrm{Cd}, \mathrm{Pb}$, were positively correlated (Table 3), while variables $\mathrm{NO}_{3}^{-}$and $\mathrm{COD}$ were negatively correlated (Table 4). Along axis F2, positive correlation concerned: tryptophan (tryptophan- 
like), tyrosine (tyrosine-like), $\mathrm{Cr}, \mathrm{BOD}_{5}$ and negative correlation affected $\mathrm{Li}, \mathrm{Sr}$ and $\mathrm{SO}_{4}{ }^{2-}$ (Table 4).

According to positive F1 axis in the distribution of the observations (F1-F2) (Fig. 7b), the highest contamination by anthropogenic metals ( $\mathrm{Al}, \mathrm{Mn}, \mathrm{Zn}, \mathrm{Cd}, \mathrm{Pb}, \mathrm{Fe}$ and $\mathrm{As}$ ) corresponds to C3 and C5 stations during the dry period (Fig. 3), which were affected by untreated domestic sewages, agricultural effluents and technical landfill center discharges as previously observed. In contrast (negative F1), the prevalence of high $\mathrm{NO}_{3}{ }^{-}$and $\mathrm{COD}$ levels in $\mathrm{M} 1, \mathrm{M} 3$, C3, C5, and C6 stations during wet period confirmed the influence of fertilizers source of organic compounds and nutriment through soil leaching (Nehme et al. 2013).

As already highlighted in the previous section, (Fig. 4) Sr was positively correlated with Li and also with $\mathrm{Cl}^{-}$(Table 4), confirming the common origin of these components from saline soils of the watershed (Nishio et al. 2010). The additional presence of $\mathrm{SO}_{4}{ }^{2-}$ arising from local evaporated rocks (Le Pape et al. 2013), was also positively correlated with $\mathrm{Sr}$ and $\mathrm{Li}$, confirming the natural origin of this compound. According to negative F2 axis, the highest concentrations of $\mathrm{Li}, \mathrm{Sr}, \mathrm{Cl}^{-}$and $\mathrm{SO}_{4}{ }^{2-}$ were recorded at $\mathrm{M} 1$ and $\mathrm{M} 3$ stations during dry period (Fig. 2, 4), as a consequence of high evaporation. These results confirmed that the water composition of Mina river was mainly influenced by natural geological sources, namely saline Solonchack soils, more markedly during the dry period. In contrast (positive F2), Cr was highly positively correlated with $\mathrm{BOD}_{5}$ (Table 4) and their high values corresponded to urban discharges at $\mathrm{C} 4$ station during wet period (Fig. 2, 3). The presence of $\mathrm{Cr}$ arising from artisanal tannery activities together with high contents of organic matter from untreated domestic wastes, confirmed that this element was mainly rejected through domestic wastes (Koukal et al. 2004). Tryptophan was highly positively correlated with tyrosine and $\mathrm{NO}_{2}{ }^{-}$ (Table 4), showing the presence of high bacterial activities (Osburn et al. 2012; Stedmon et al. 2008) in M2 and C4 stations (urban sewages), particularly during the dry period. There microbial activities may be related to several types of bacteria, of which fecal coliforms such as Escherichia coli and fecal enterococci like Enterococcus faecalis are the most abundant (Ammor 2007; French guidelines 2016). The correlation between TSM and the presence of tryptophan and tyrosine (fingerprints of sewage waters) (Table 4) confirmed that these wastewaters were not treated before their rejection into the rivers. On the other hand, these urban sewages (M2 and C4 stations) contained more specifically particulate materials (TSM) positively correlated with $\mathrm{Cu}$ and $\mathrm{As}$ (Table 4). These correlations showed that $\mathrm{Cu}$ and $\mathrm{As}$ could be associated to TSM, which facilitated the transport and the distribution of metallic contamination through these urban discharges along the watercourse. 


\section{Conclusion}

This study highlighted the multi-dimensional and multi-factorial aspects of Cheliff watershed pollution. Urban discharges (M2, C4) are a major source of water organic pollution, with high COD values largely exceeding the upper limit of guidelines. The inputs of untreated sewages were characterized by high concentrations of tryptophan-like and tyrosine-like compounds, confirming these amino acids as fingerprints of untreated urban discharges. A metallic contamination by $\mathrm{Fe}$ and $\mathrm{Cr}$ was also evidenced in $\mathrm{C} 4$ station, which may be correlated with local craft activities.

The synchronous monitoring and assessment of physicochemical parameters, fluorescent organic compounds and metallic elements of Cheliff river waters highlighted its global contamination, mainly in its downstream part (C3, C5 and C6).

Cheliff river was especially affected by organic pollution (COD) during the wet period, and by metallic contamination ( $\mathrm{Fe}$ and $\mathrm{Al}$ ) during dry period with concentrations greatly exceeding the guidelines.

During wet period, the water quality of Cheliff river (C3, C5 and C6) was affected by high concentrations of $\mathrm{NO}_{3}{ }^{-}$and $\mathrm{Cu}$ mainly related to intense agricultural activities. The influence of metallic elements ( $\mathrm{Zn}, \mathrm{Mn}, \mathrm{As}, \mathrm{Pb}, \mathrm{Cd}$ ) and fluorescent organic components (tryptophanlike) was greater during the dry period. This chronic contamination was related to untreated domestic sewages, agricultural effluents and technical landfill center discharges in this area. Diffuse pollutions were also evidenced, which made the identification of different contamination sources complicated.

Mina river was mostly affected by non-treated domestic sewages with high COD levels during wet period and high $\mathrm{BOD}_{5}$ during dry period, exceeding the guideline limits. This tributary was also influenced by agricultural activities through $\mathrm{NO}_{3}{ }^{-}$inputs mainly during wet period, as a consequence of leaching. The presence of $\mathrm{Li}, \mathrm{Sr}, \mathrm{SO}_{4}{ }^{2-}$ and $\mathrm{Cl}^{-}$indicated the contribution of natural influence from saline soil of Mina valley, more specifically during dry period.

As illustrated in this report, untreated urban sewages combined to industrial and agricultural activities greatly contributed to the degradation of water quality of Cheliff and Mina rivers. Considering the rapid demographic growth, the improvement of water quality represents a real challenge for the Cheliff river which is used as the main water resource for irrigation and drinking water in the North-West region of Algeria. 


\section{References}

AFNOR (1999) Association Française de Normalisation. Qualité de l'eau: collection, environnement, Paris-La Défense, 1733 p

Agence du bassin hydrographique Cheliff-Zahrez. Available from: http://abh-cz.com.dz. Accessed 6 December 2017

Algerian guidelines (2011) Décret exécutif n¹1-219 du 20 Rabie El Aouel 1432, correspondant au 12 avril 2011. Normes Algériennes de la qualité des eaux superficielles et souterraines destinées à l'alimentation en eau potable des populations. Journal Officiel de la République Algérienne Démocratique et Populaire

Algerian guidelines (2012) Arrêté interministériel du 8 safar, correspondant au 2 janvier 2012. Spécifications des Eaux Usées Epurées Utilisées à des Fins d'Irrigation. Journal Officiel de la République Algérienne Démocratique et Populaire

Ammor MS (2007) Recent Advanced in the Use of Intrinsic Fluorescence for Bacterial Identification and Characterization. J Fluoresc 17: 455-459

Baker A (2001) Fluorescence excitation- emission matrix characterization of some sewageimpacted rivers. Environ.Sci. Technol 35: 948-953

Baker A, Inverarity R, Charlton M, Richmond S (2003) Detecting river pollution using fluorescence spectrophotometry: case studies from the Ouseburn, NE England. Environ Pollut 124: 57-70

Baker A, Spencer RG (2004) Characterization of dissolved organic matter from source to sea using fluorescence and absorbance spectroscopy. Sci Total Environ 333: 217-232

Belhadj M, Ghezzar M, Abdelmalek F, Benahmed AA, Ouddane B, Addou A (2006) Assessment of the sediment contamination by heavy metals of the Chéliff river, Algeria. FRESEN ENVIRON BULL 15 (3): 186-192

Benson-Evans K, Antoine S, Randerson P, Al-Asadi MS (2006) Ecological studies of three West Algerian rivers: The river Cheliff and its tributary, the river Mina. Mesopot. J .Mar. Sci 21(2): 175-196 
Bouabdli A, Saidi N, M'Rabet S, Escarre J, Leblanc M (2005) Heavy metal transport by the Moulouya River (Morocco). Rev. Sci. Eau 18 (2): 199-213

Boulaine MJ, Bellon J (1955) Carte de reconnaissance des sols de la région de Mostaganem (Algeria). Gouvernement Général de l'Algérie

Bro R, Kiers HA (2003) A new efficient method for determining the number of components in PARAFAC models. J Chemom 17: 274-286

Bu H, Song X, Guo F (2017) Dissolved trace elements in a nitrogen-polluted river near to the Liaodong Bay in Northeast China. Mar Pollut Bull 114: 547-554

Çadraku H, Gashi F, Shala A, Fetoshi O (2016) Variations in the Physico-Chemical Parameters of under groundwater of Blinaja catchment, Kosovo. IFAC_PapersOnline 49-29: 200-205

Carstea EM, Baker A, Pavelescu G, Boomer I (2009) Continuous fluorescence assessment of organic matter variability on the Bournbrook River, Birmingham, UK. Hydrol Process 23: $1937-1946$

Chen W, Westerhoff P, Leenheer JA, Booksh K (2003) Fluorescence excitation- emission matrix regional integration to quantify spectra for dissolved organic matter. Environ. Sci. Technol 37: 5701-5710

Cruz MAS, Gonçalves A, de Arago R, de Amorium JRA, Melo da Mota PV, Srinivasan VS, et al (2019) Spatial and seasonal variability of the water quality characteristics of a river in Brazil. Environ Earth Sci 78: 68. https://doi.org/10.1007/s12665-019-8087-5

Daoud Y, Cheverry C, Robert M (1993) Rôle du magnésium dans les sols salés des plaines du Chéliff (Algérie). Sci. Sol AFES 31 (4): 281-293

Direction d'hydraulique de Mostaganem (Algeria) (2013). Available from:http://wilayamostaganem.dy-webs.com/developpement-local/hydraulique. Accessed 11 November 2017

Douaoui A, Hervé N, Walter C (2006) Detecting salinity hazards within a semiarid context by means of combining soil and remote-sensing data. Geoderma: 134: 217-230 
Douaoui A, Walter C, Gouar A, Hammoudi S (2001) Assessment of the topsoil structural degradation of the lower Cheliff Valley (Algeria)-application of multivariate analysis. 4th conference of the Working Group on Pedometrics (WG-PM), Ghent, 19-21 september

Duée PH, Jung J, Gueugneau AM (1973) Composition en acides aminés du lait de truie. Ann Zootech 22 (2): 243-247

Effendi H (2016) River water quality preliminary rapid assessment using pollution index. Procedia Environ Sci 33: 562-567.

Elewa HH (2010) Potentialities resources pollution of the Nile River Delta, Egypt. Open Hydrol J 4: 1-13

French guidelines (2013) Arrêté officiel du 25 décembre 2013 fixant les normes françaises des eaux destinées à la consommation humaine, code de la santé publique : Articles R.1321-1 à R.1321-66 et annexes 13-1 au 13-3. Journal Officiel de la République Française

French guidelines (2016) Instruction interministérielle nDGS/EA4/DEB/DGBE/2016/135 du 26 avril 2016 relative à la réutilisation des eaux usées traitées pour l'irrigation de cultures et d'espaces verts. Journal Officiel de la République Française

Hammou A (2012) Charactéristiques de la fluorescence des eaux du fleuve côtier Têt (Pyrénées-Orientales) en relation avec la matière organique naturelle du bassin versant: utilisation de l'algorithme PARAFAC. PhD Thesis. University of Perpignan Via Domitia (France), $271 \mathrm{p}$

Houhou J, Lartiges BS, France-Lanord C, Guilmette C, Poix S, Mustin C (2010) Isotopic tracing of clear water sources in an urban sewer: A combined water and dissolved sulphates stable isotope approach. Water Res 44: 256-266

Hudson N, Baker A, Ward D, Reynold DM, Brundson C, Carliell-Marquet Ch, et al (2008) Can fluorescence spectrometry be used as a surrogate for the Biochemical Oxygen Demand (BOD) test in water quality assessment? An example from South West England. Sci Total Environ 391: 149-158 
Kabata-Pendias A, Szteke B (2015) Trace elements in abiotic and biotic environments. CRC Press Taylor\& Francis Group Boca Raton, London, 393p

Koukal B, Dominik J, Vignati D, Arpagaus P, Santiago S, Ouddane B, et al (2004) Assessment of water quality and toxicity of polluted Rivers Fez and Sebou in the region of Fez (Morocco). Environ Pollut 131: 163-172

Laiche A (2017) Origines de la salinisation des eaux et des sols d'une zone à climat semiaride: cas de Remila (W. Khenchela). PhD Thesis. University of Biskra (Algeria), 215 $\mathrm{p}$

Le Pape P, Ayrault S, Michelot JL, Monvoisin G, Noret A, Quantin C (2013) Building an isotopic hydrogeochemical indicator of anthropogenic pressure on urban rivers. Chem Geol 344: 63-72

Mendiguchía C, Moreno C, García-Vargas M (2007) Evaluation of natural and anthropogenic influences on the Guadalquivir River (Spain) by dissolved heavy metals and nutrients. Chemosphere 69: 1509-1517

Naimi Ait-Aoudia M, Berezowska-Azzag E (2016) Water resources carrying capacity assessment : the case of Algeria's capital city. Habitat Int 58: 51-58

Nehme N, Haydar C, Koubaissy B, Fakih M, Awad S, Toufaily J, et al (2013) Evaluation of the Physicochemical Characteristics of Water in the Lower Litani Basin, Lebanon. Elixir Journal 62: 17478-17484

Nishio Y, Okamura K, Tanimizu M, Ishikawa T, Sano Y (2010) Lithium and strontium isotopic systematics of waters around Ontake volcano, Japan: Implications for deepseated fluids and earthquake swarms. Earth Planet. Sci. Lett 297: 567-576

Office National d'Assainissement de Relizane (Algeria) (2014). Available from: http://www.ona-dz.org. Accessed 11November 2017.

Ohno T (2002) Fluorescence inner-filtering correction for determining the humification index of dissolved organic matter. Environ. Sci. Technol 36: 742-746

Olivier P, Radakovitch O, Hamelin B (2011) Major and trace element partition and fluxes in the Rhône River. Chem Geol 285: 15-31 
Osburn CL, Handsel LT, Mikan MP, Paerl HW, Montogomery MT (2012) Fluorescence tracking of dissolved and particulate organic matter quality in a river-dominated estuary. Environ. Sci. Technol 46: 8628-8636

Perrin JL, Raïs N, Chahinian N, Moulin P, Ijjaali M (2014) Water quality assessment of highly polluted rivers in a semi-arid Mediterranean zone Oued Fez and Sebou River (Morocco). J Hydrol 510: 26-34

Salam MA, Kabir MM, Yee LF, Khan MS (2019) Water Quality Assessment of Perak River, Malaysia. j poll 5 (3): 637-648

Singh KK, Sharma BM, Usha KH (2010) Ecology of Kharungpat lake, Thoubal, Manipur, India: part-I water quality status. Ecoscan 4 ( 2 \& 3): 241-245

Stedmon CA, Bro R (2008) Characterizing dissolved organic matter fluorescence with parallel factor analysis: a tutorial. Limnol Oceanogr 6: 572-579

Strady E, Dang VBH, Némery J, Guédron S, Dinh QT, Denis H et al (2017) Baseline seasonal investigation of nutrients and trace metals in surface waters and sediments along the Saigon River basin impacted by the megacity of Ho Chi Minh (Vietnam). Environ Sci Pollut Res 24: 3226-3243

Tutiempo Network TN. (2018). Available from: https://tutiempo.net/. Accessed 14 November 2018.

Vouvé F, Cunha LCda, Serve L, Salmon JV, Salmon JM (2009) Spatio-temporal variations of fluorescence properties of dissolved organic matter along the River Têt (PyrénéesOrientales, France). Chem Ecol 25: 435-452

Winter AR, Fish TAE, Playle RC, Scott Smith D, Jefferson Curtis P (2007) Photodegradation of natural organic matter from diverse freshwater sources. Aquat Toxicol 84: 215-222

World databank (2017). Available from: https://data.worldbank.org. Accessed 6 December 2017.

Yan W, Li J, Bai X (2016) Comprehensive assessment and visualized monitoring of urban drinking water quality. Chemom. Intell. Lab. Syst 155: 26-35 
Yu H, Song Y, Gao H, Liu L, Yao L, Peng J (2015) Applying fluorescence spectroscopy and multivariable analysis to characterize structural composition of dissolved organic matter and its correlation with water quality in an urban river. Environ. Earth.Sci 73: $5163-5171$

Zhaoyong Z, Abuduwaili J, Jiang F (2015) Heavy metal contamination, sources, and pollution assessment of surface water in the Tianshan Mountains of China. Environ Monit Assess 33: 187-200

\section{List of figure captions}

Fig.1 Localisation of study area: the lower Cheliff and Mina basin located in the extreme northern part of the Cheliff basin (a). Sampling stations along Cheliff and Mina rivers were indicated by green points (b). Localisation of pollution inputs (urban discharges, technical landfill center, desalination plant) and distances between stations are notified (c).

Fig.2 Spatio-temporal variations of physicochemical parameters (conductivity, TSM, $\mathrm{SO}_{4}{ }^{2-}$, $\mathrm{Cl}^{-}, \mathrm{NO}_{2}^{-}, \mathrm{NO}^{3-}, \mathrm{COD}, \mathrm{BOD}_{5}$ ) in urban discharges (M2 and $\left.\mathrm{C} 4\right)$, Mina river (M1 and M3) and Cheliff river (C1, C2, C3, C5 and C6). The dotted line corresponds to the Algerian guidelines for surface waters intended for production of drinking water.

Fig.3 Spatio-temporal variations of metal elements $(\mathrm{Cu}, \mathrm{Zn}, \mathrm{Fe}, \mathrm{Al}, \mathrm{Mn}, \mathrm{Cr}, \mathrm{Ni}, \mathrm{As}, \mathrm{Cd}, \mathrm{Pb})$ in urban discharges (M2 and C4), Mina river (M1 and M3) and Cheliff river (C1, C2, C3, C5 and C6). The dotted line corresponds to the Algerian guidelines for surface waters intended for production of drinking water. The continuous line corresponds to the French guidelines for surface waters intended for production of drinking water.

Fig.4 Relationships between $\mathrm{Li}$ and $\mathrm{Sr}$ concentrations $\left(\mu \mathrm{g} .1^{-1}\right)$ in urban discharges (M2 and C4), Mina river (M1 and M3) and Cheliff river (C1, C2, C3, C5 and C6) for both seasons. Rhombus corresponds to Mina river stations, square corresponds to Cheliff river stations. The full rhombus and square corresponds to the dry period, the empty rhombus and square corresponds to the wet period.

Fig.5 FEEMs characteristic from DOM in urban discharge (C4) and in waters of Cheliff river (C3, C5) at both seasons. Fluorescence intensity (F.I) in arbitrary units (a.u.).

Fig.6 Spatio-temporal variations of tryptophan-like and tyrosine-like in urban discharges (M2 and C4), Mina river (M1 and M3) and Cheliff river (C1, C2, C3, C5 and C6) for both seasons. 
Fig.7 Results of PCA plotted according to axes 1-2. Distribution of physicochemical, fluorescent and metallic compounds (a). Distribution of observations in urban discharges (M2 and C4), Mina river (M1 and M3) and Cheliff river (C1, C2, C3, C5 and C6) at both seasons (b). Tryptophan-like was noted Tryptophan; Tyrosine-like was noted Tyrosine. 
Figure 1
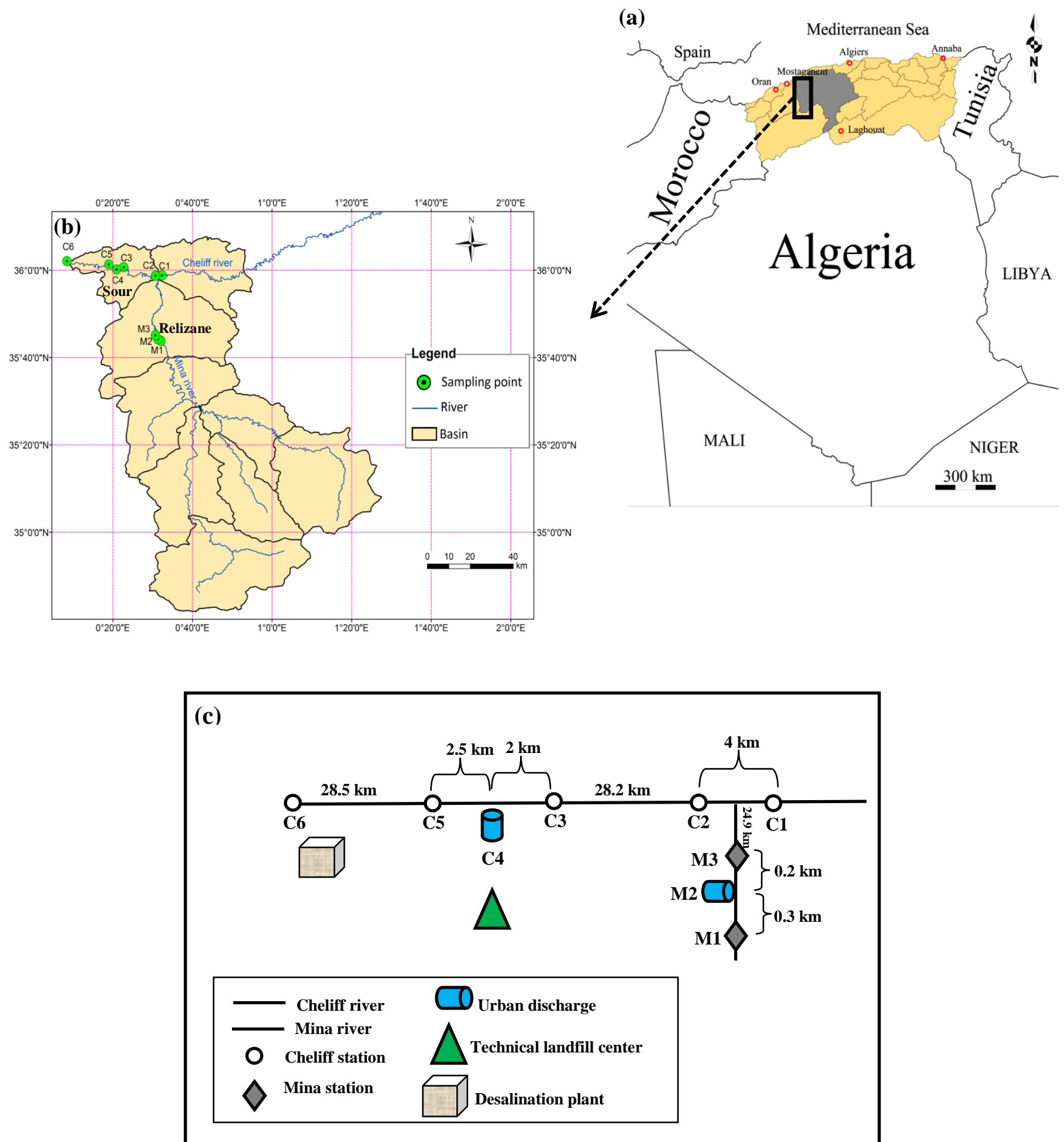
Figure 2
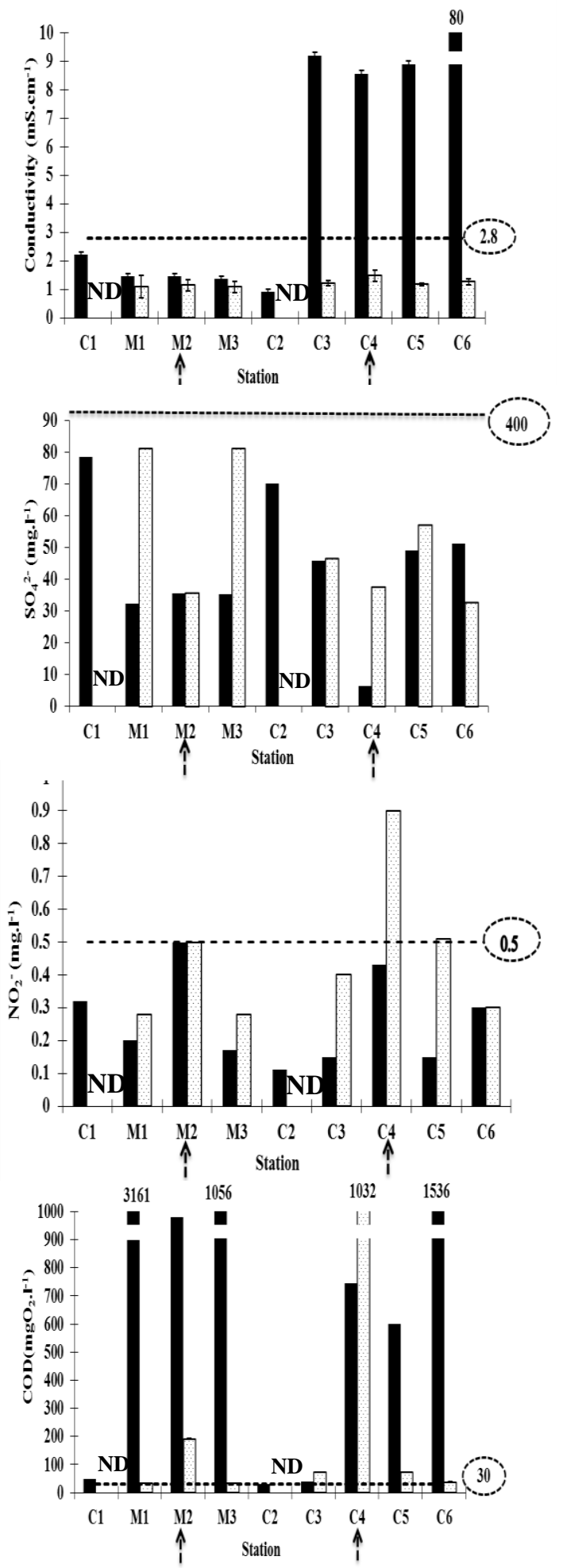

- - Algerian guidelines for surface waters intended for production of drinking water

- Wet period

$\square$ Dry period

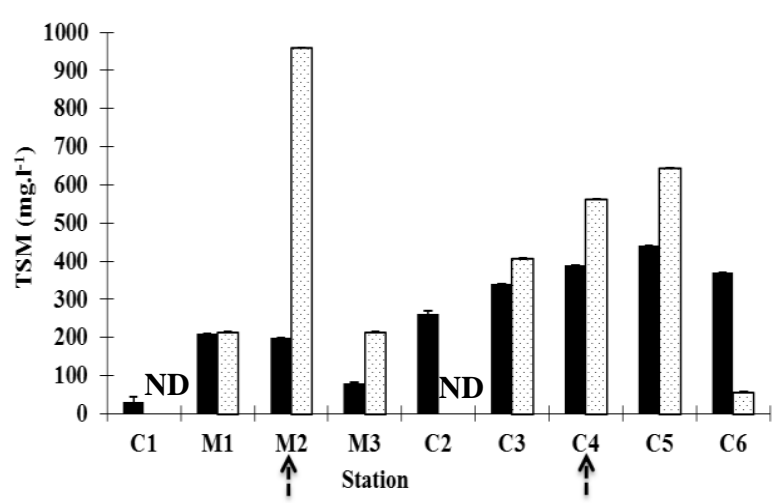

— Wet period

$\square$ Dry period

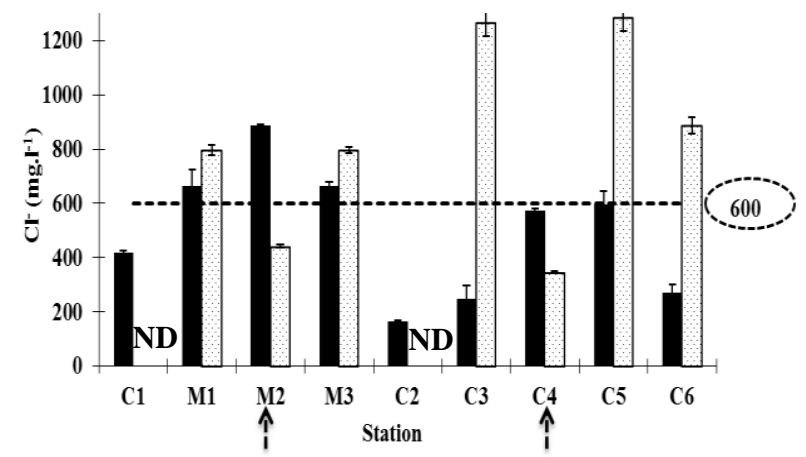

50
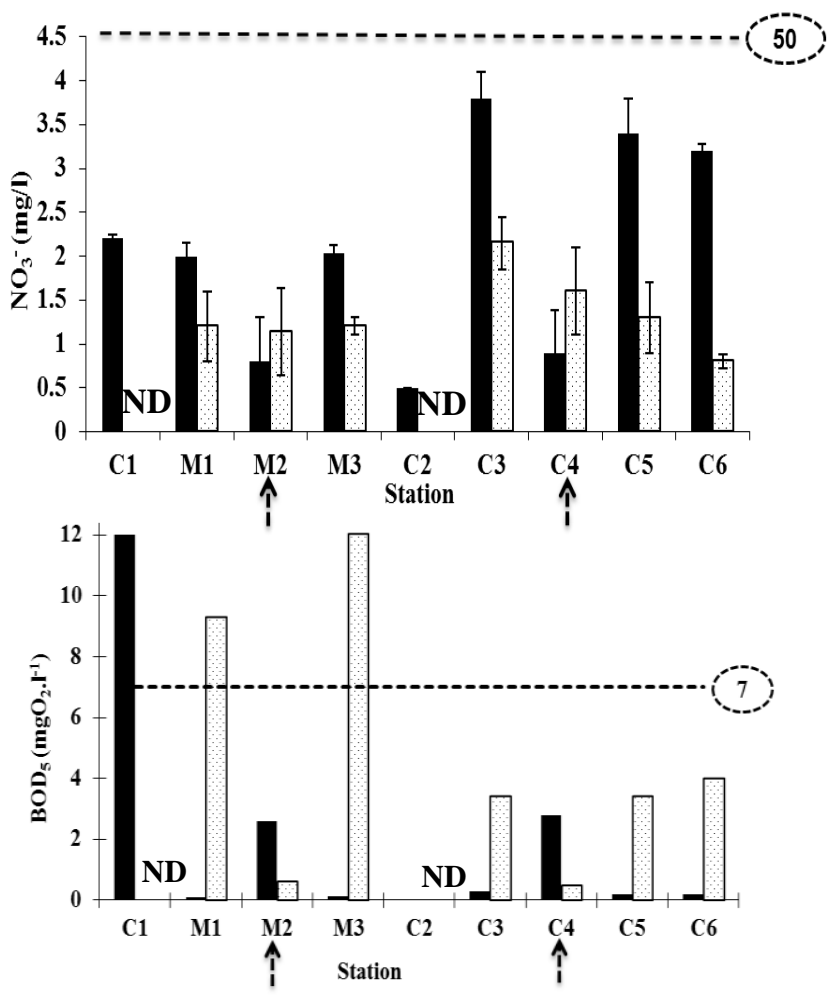

† Urban discharge ND no data 
Figure 3
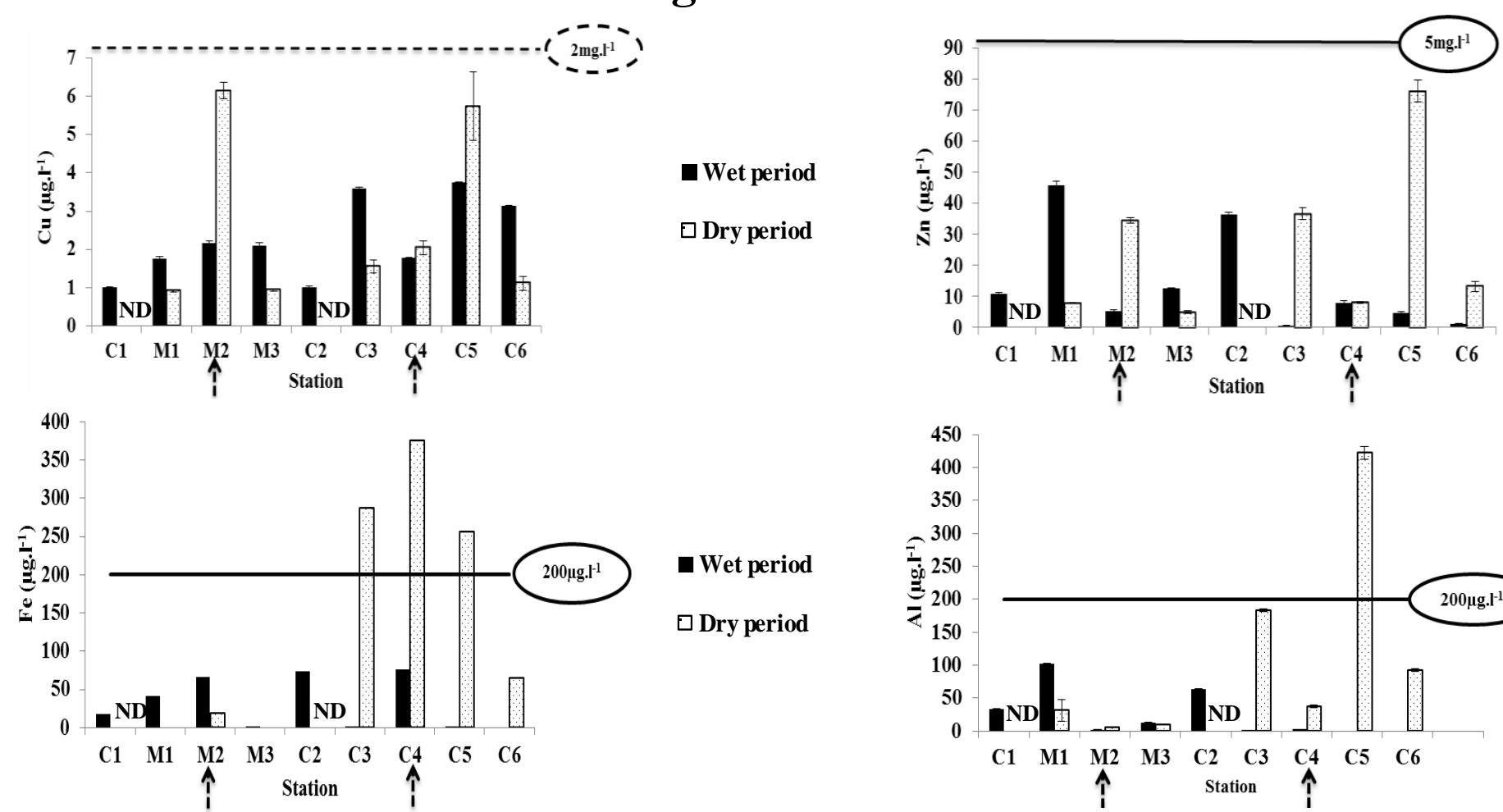

$\square$ Wet period
$\square$ Dry period
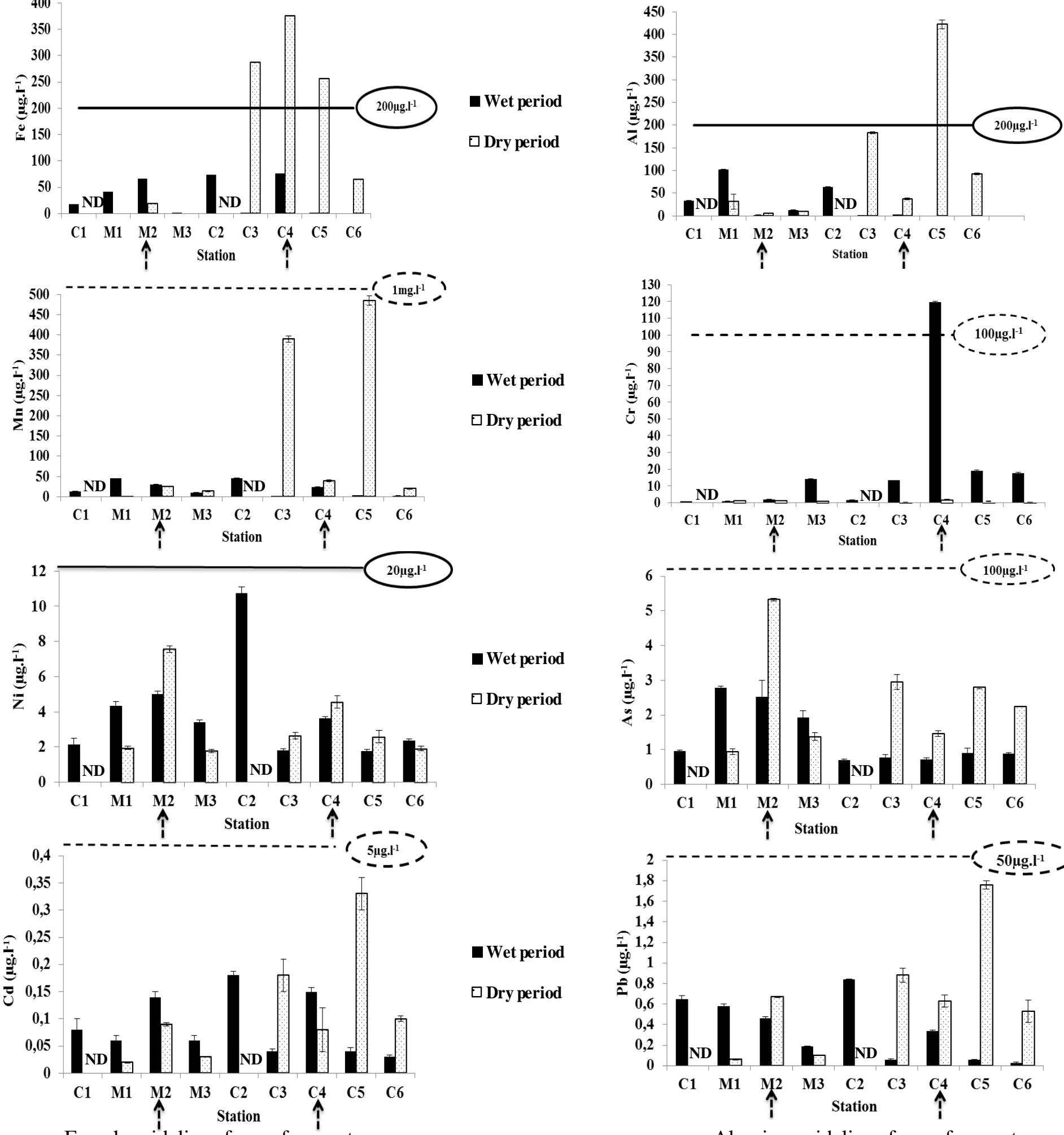

Wet period

$\square$ Dry period
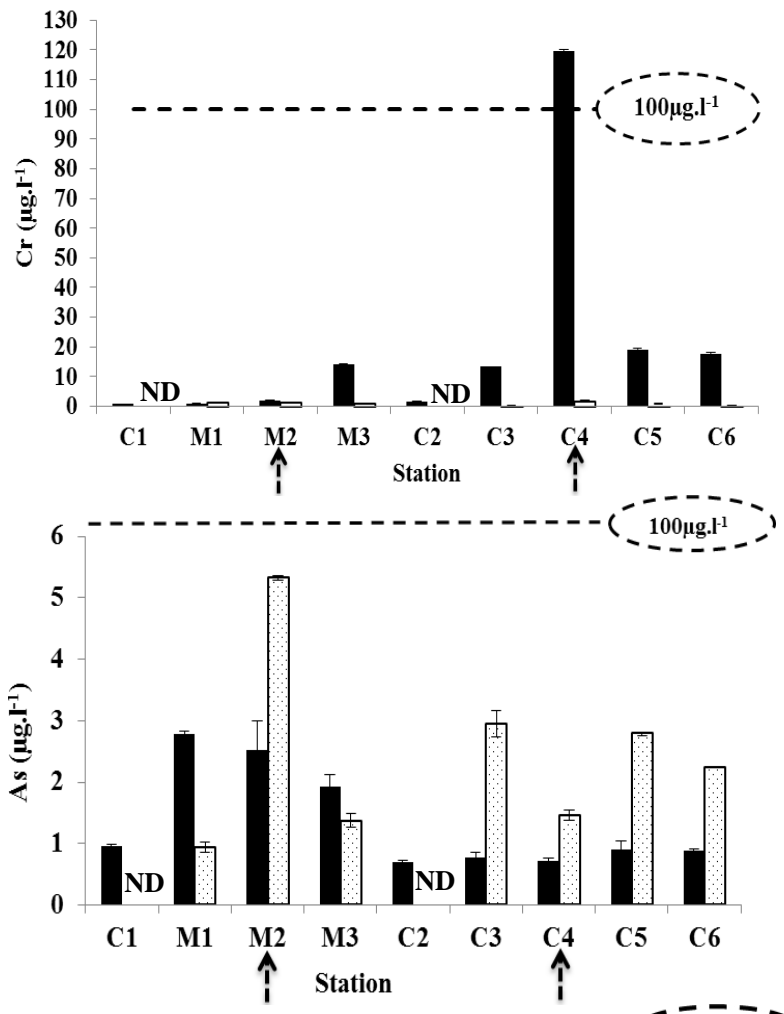

- Wet period

$\square$ Dry period

French guidelines for surface waters

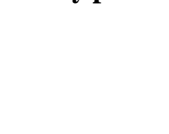

—Wet period

intended for production of drinking water 


\section{Figure 4}

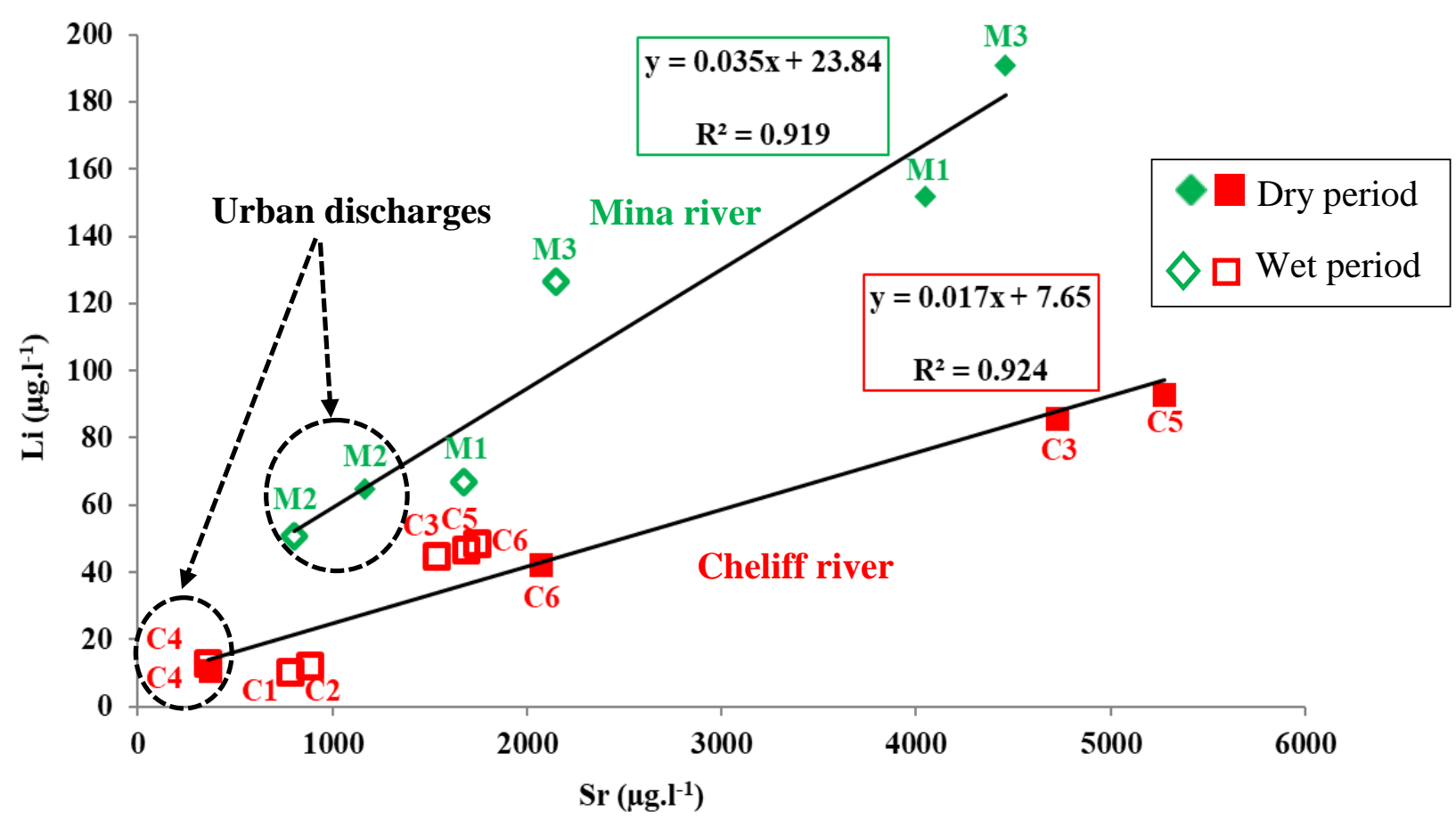




\section{Figure 5}

Wet period

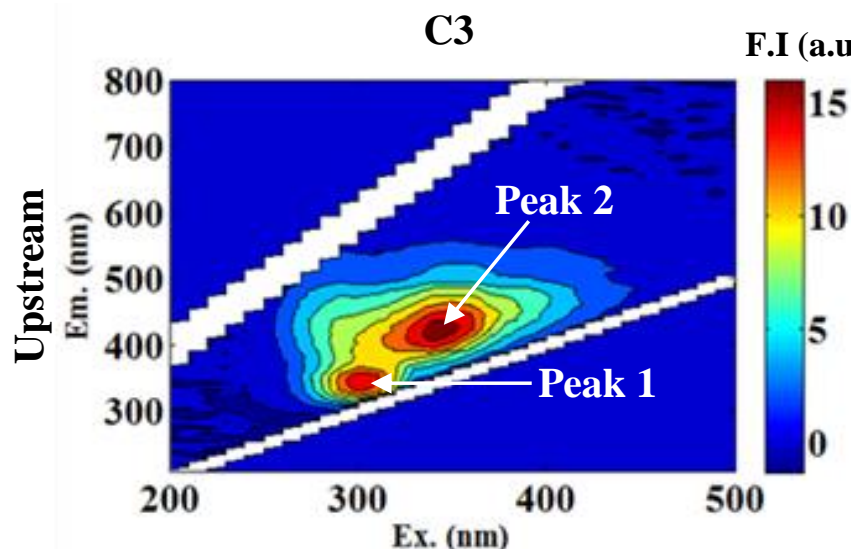

C4

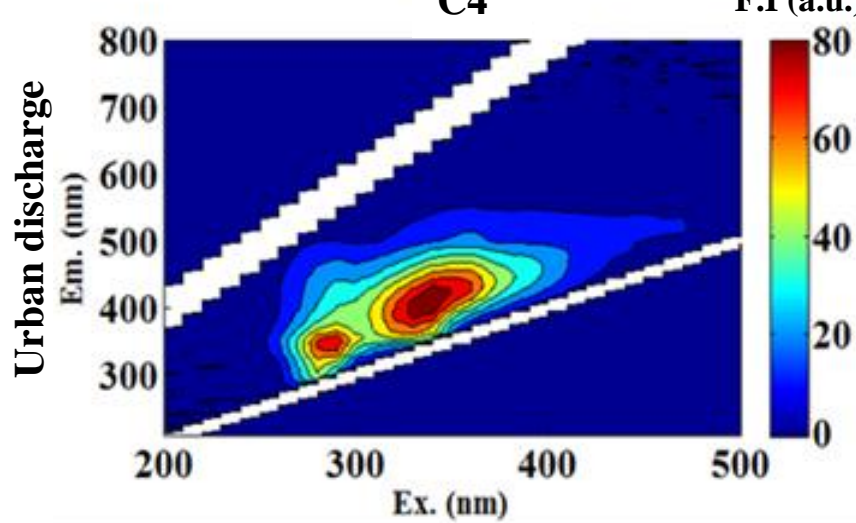

C5

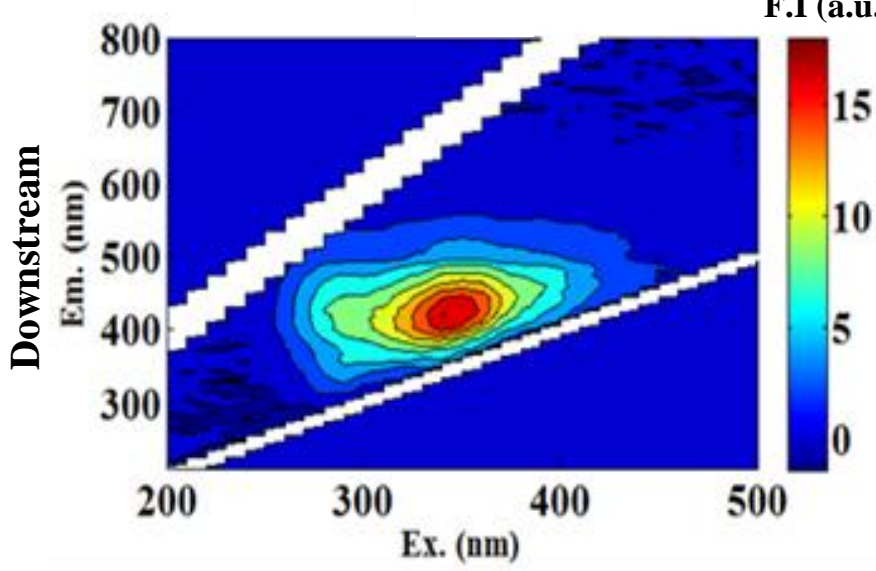

\begin{tabular}{cccc}
\hline Peak & $\begin{array}{c}\text { Excitation } \\
\text { max (nm) }\end{array}$ & $\begin{array}{c}\text { Emission } \\
\mathbf{m a x}(\mathbf{n m})\end{array}$ & $\begin{array}{c}\text { Assignment and } \\
\text { probable origin 1,2,3 }\end{array}$ \\
\hline 1 & $275-280$ & $340-344$ & Aromatic amino acids \\
\hline 2 & $320-360$ & $420-460$ & $\begin{array}{c}\text { Terrestrial humic } \\
\text { substances }\end{array}$ \\
\hline
\end{tabular}

Dry period

C3 F.I (a.u.)

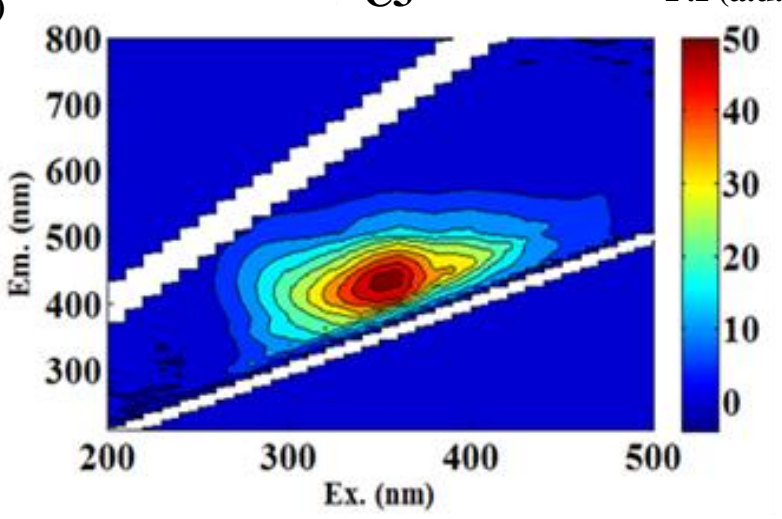

C4

F.I (a.u.)

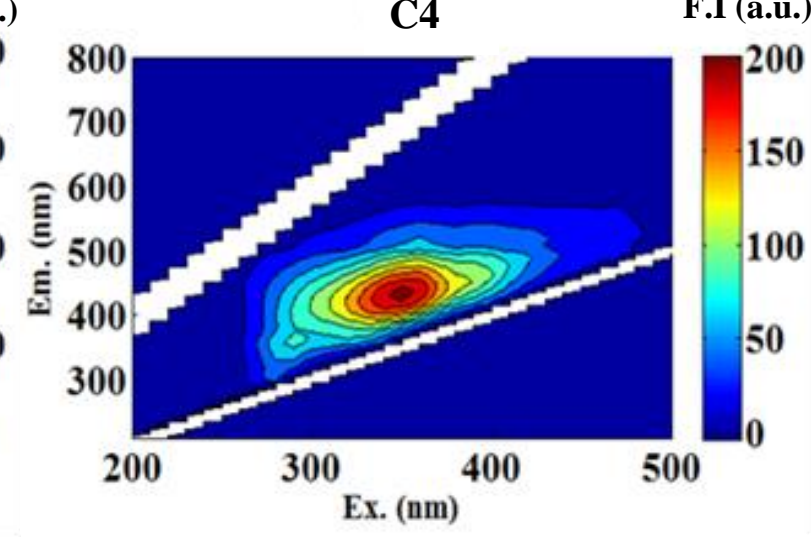

C5.) F.I (a.u.)

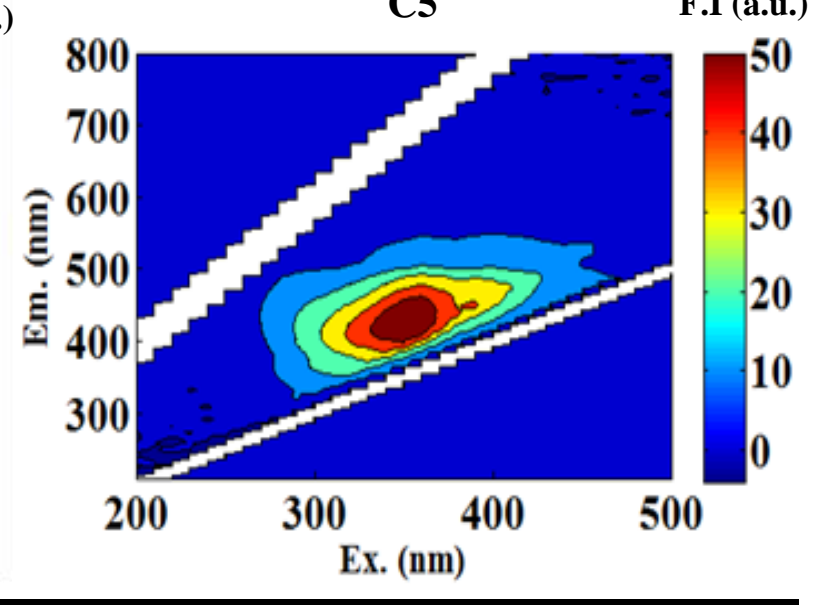
probable origin $1,2,3$

$\left({ }^{1}\right.$ Chen et al.2003 ; ${ }^{2}$ Osburn et al. $2012 ;{ }^{3}$ Yu et al. 2015) 


\section{Figure 6}
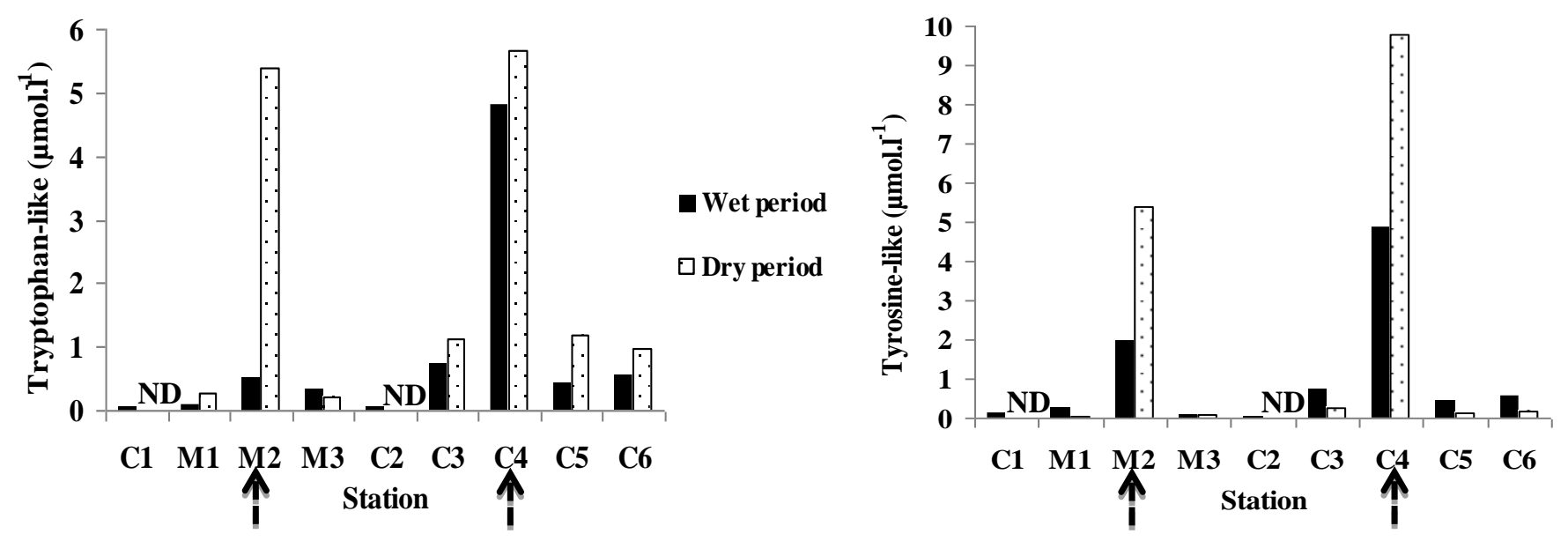

† Urban discharge ND no data 
Figure 7
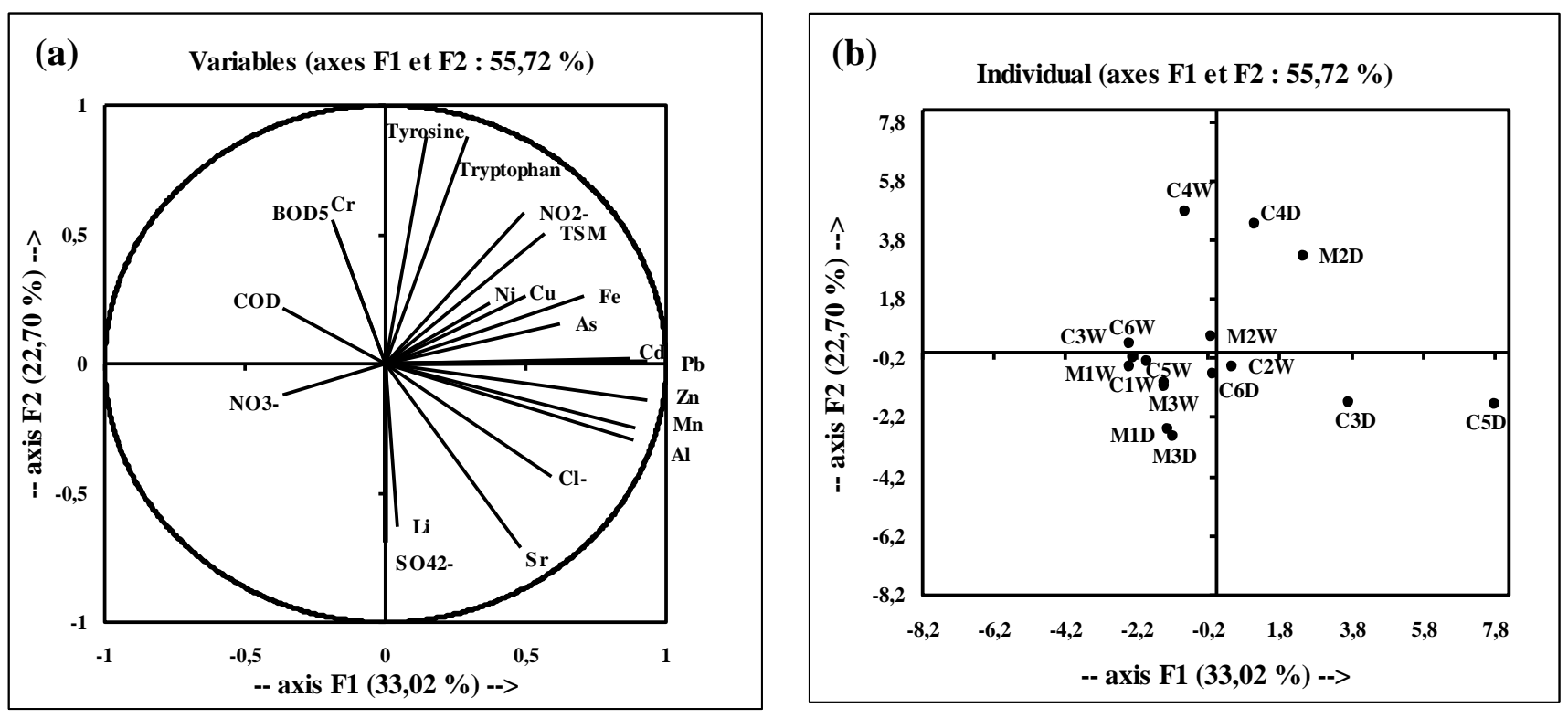
Table.1 The detection limits of instrument for each metal $(\mathrm{Cu}, \mathrm{Zn}, \mathrm{Al}, \mathrm{Fe}, \mathrm{Mn}, \mathrm{Cd}, \mathrm{Pb}, \mathrm{As}, \mathrm{Ni}$, $\mathrm{Cr}, \mathrm{Sr}$ and $\mathrm{Li}$ ) were presented $\left(\mu \mathrm{g} \cdot \mathrm{g}^{-1}\right)$. The recovery percentages of metallic elements analysis were also notified.

\begin{tabular}{ccc}
\hline Metallic elements & $\begin{array}{c}\text { Detection limit } \\
\left(\boldsymbol{\mu g ^ { - 1 }} \mathbf{g}^{-1}\right)\end{array}$ & $\begin{array}{c}\text { Recovery } \\
(\boldsymbol{\%})\end{array}$ \\
\hline $\mathrm{Cu}$ & 0.1 & 100 \\
\hline $\mathrm{Zn}$ & 0.1 & 103 \\
\hline $\mathrm{Al}$ & 0.3 & 81 \\
\hline $\mathrm{Fe}$ & 0.5 & 105 \\
\hline $\mathrm{Mn}$ & 0.1 & 103 \\
\hline $\mathrm{Cd}$ & 0.1 & 104 \\
\hline $\mathrm{Pb}$ & 0.1 & 102 \\
\hline $\mathrm{As}$ & 0.1 & 97 \\
\hline $\mathrm{Ni}$ & 0.1 & 99 \\
\hline $\mathrm{Cr}$ & 0.1 & 101 \\
\hline $\mathrm{Sr}$ & 0.1 & 98 \\
\hline $\mathrm{Li}$ & 0.1 & 105 \\
\hline
\end{tabular}


Table.2 Comparison of some parameter concentrations $\left(\mathrm{Cl}^{-}, \mathrm{BOD}_{5}, \mathrm{SO}_{4}{ }^{2-}\right.$ and Tryptophan) in waters from Cheliff river (present study) and others selected rivers.

\begin{tabular}{|c|c|c|c|c|c|}
\hline \multirow[t]{2}{*}{ Parameters } & \multicolumn{5}{|c|}{ Concentrations in river water } \\
\hline & $\begin{array}{c}\text { Cheliff } \\
\text { (Present study) }\end{array}$ & $\begin{array}{l}\text { Cheliff }^{1} \\
\text { (Algeria) }\end{array}$ & $\begin{array}{c}\text { Sebou }^{2} \\
\text { (Morocco) }\end{array}$ & $\begin{array}{c}\text { Nil }^{\mathbf{3}} \\
\text { (Egypt) }\end{array}$ & $\begin{array}{c}\text { Têt }^{4} \\
\text { (France) }\end{array}$ \\
\hline $\mathrm{Cl}^{-}\left(\mathrm{mg} \cdot \mathrm{l}^{-1}\right)$ & $166-1287$ & $100-1000$ & $120-219$ & 5 & l \\
\hline $\mathrm{BOD}_{5}\left(\mathrm{mg} \mathrm{O}_{2} \cdot \mathrm{l}^{-1}\right)$ & $0.0-12.0$ & $0.6-4.8$ & 2.3 & 3.1 & I \\
\hline $\mathrm{SO}_{4}^{2-}\left(\mathrm{mg} \cdot \cdot^{-1}\right)$ & $30.0-81.0$ & I & $19.0-107.5$ & 0.5 & I \\
\hline Tryptophan $\left(\mu \mathrm{mol} \mathrm{l}^{-1}\right)$ & $0.06-1.20$ & l & I & I & $0.03-0.24$ \\
\hline
\end{tabular}

${ }^{1}$ Benson-Evans et al. (2006)

2 Koukal et al. (2004)

${ }^{3}$ Elewa H (2010)

${ }^{4}$ Hammou (2012) 
Table.3 Comparison of Trace metals concentrations $(\mathrm{Cu}, \mathrm{Zn}, \mathrm{Mn}, \mathrm{Ni}, \mathrm{Cd}$ and $\mathrm{Pb})$ in waters from Cheliff river (present study) and others selected rivers.

\begin{tabular}{cccccc}
\hline Metals & \multicolumn{5}{c}{ Concentrations in river water $\left(\boldsymbol{\mu g . \mathbf { l } ^ { \mathbf { 1 } } )}\right.$} \\
\hline $\begin{array}{c}\text { Cheliff } \\
(\text { Present study) }\end{array}$ & $\begin{array}{c}\text { Moulouya }^{\mathbf{1}} \\
(\text { Morocco) }\end{array}$ & $\begin{array}{c}\text { Guadalquivir }^{\mathbf{2}} \\
(\text { Spain})\end{array}$ & $\begin{array}{c}\text { Nil }^{\mathbf{3}} \\
(\text { Egypt })\end{array}$ & $\begin{array}{c}\text { Rhône }^{\mathbf{4}} \\
(\text { France })\end{array}$ \\
\hline $\mathrm{Cu}$ & 5.7 & 2.2 & 2.6 & 2.0 & 0.4 \\
\hline $\mathrm{Zn}$ & 76.1 & $/$ & 1.6 & 5.0 & 5.8 \\
\hline $\mathrm{Mn}$ & 484.4 & 6.3 & 20.6 & 40.0 & $/$ \\
\hline $\mathrm{Ni}$ & 10.7 & $/$ & 2.3 & 5.0 & $/$ \\
\hline $\mathrm{Cd}$ & 0.30 & 0.03 & 0.01 & 2.00 & $/$ \\
\hline $\mathrm{Pb}$ & 1.76 & 0.35 & 0.17 & 5.00 & 0.01 \\
\hline
\end{tabular}

${ }^{1}$ Bouabdli et al. (2005)

${ }^{2}$ Mendiguichia et al. (2007)

${ }^{3}$ Elewa H (2010)

${ }^{4}$ Olivier et al. (2011) 
Table.4 Pearson correlation matrix of physicochemical (TSM, $\mathrm{SO}_{4}{ }^{2-}, \mathrm{Cl}^{-}, \mathrm{NO}_{2}{ }^{-}, \mathrm{NO}_{3}{ }^{-}, \mathrm{COD}$ and $\left.\mathrm{BOD}_{5}\right)$, fluorescent (Tryptophan and Tyrosine) and metallic $(\mathrm{Cu}, \mathrm{Zn}, \mathrm{Fe}, \mathrm{Al}, \mathrm{Mn}, \mathrm{Cr}, \mathrm{Ni}$, $\mathrm{As}, \mathrm{Cd}, \mathrm{Pb}, \mathrm{Li}$ and $\mathrm{Sr}$ ) parameters in waters from Cheliff and Mina rivers. Bold values: significant correlations

\begin{tabular}{|c|c|c|c|c|c|c|c|c|c|c|c|c|c|c|c|c|c|c|c|c|c|}
\hline & COD & $\mathrm{BOD}_{5}$ & $\mathrm{Cl}^{-}$ & $\mathrm{SO}_{4}^{2-}$ & $\mathrm{NO}_{2}^{-}$ & $\mathrm{NO}_{3}^{-}$ & TSM & $\mathrm{Li}$ & $\mathrm{Al}$ & $\mathrm{Cr}$ & $\mathrm{Mn}$ & $\mathrm{Fe}$ & $\mathrm{Ni}$ & $\mathrm{Cu}$ & $\mathrm{Zn}$ & As & $\mathrm{Sr}$ & $\mathrm{Cd}$ & $\mathrm{Pb}$ & Tryptophan & Tyrosine \\
\hline COD & - & & & & & & & & & & & & & & & & & & & & \\
\hline $\mathrm{BOD}_{5}$ & 0,103 & - & & & & & & & & & & & & & & & & & & & \\
\hline $\mathrm{Cl}^{-}$ & $-0,144$ & $-0,142$ & - & & & & & & & & & & & & & & & & & & \\
\hline $\mathrm{SO}_{4}^{2-}$ & $-0,438$ & $-0,490$ & $-0,014$ & - & & & & & & & & & & & & & & & & & \\
\hline $\mathrm{NO}_{2}^{-}$ & $-0,002$ & 0,059 & 0,160 & $-0,268$ & - & & & & & & & & & & & & & & & & \\
\hline NO3- & 0,185 & $-0,064$ & $-0,274$ & 0,031 & $-0,313$ & - & & & & & & & & & & & & & & & \\
\hline TSM & $-0,101$ & 0,064 & $-0,012$ & $-0,228$ & 0,497 & 0,010 & - & & & & & & & & & & & & & & \\
\hline $\mathrm{Li}$ & $-0,121$ & $-0,285$ & 0,485 & 0,416 & $-0,211$ & $-0,088$ & $-0,109$ & - & & & & & & & & & & & & & \\
\hline $\mathrm{Al}$ & $-0,312$ & $-0,186$ & 0,665 & 0,139 & 0,241 & $-0,192$ & 0,271 & 0,111 & - & & & & & & & & & & & & \\
\hline $\mathrm{Cr}$ & 0,085 & 0,976 & $-0,142$ & $-0,560$ & 0,021 & $-0,053$ & 0,055 & $-0,279$ & $-0,203$ & - & & & & & & & & & & & \\
\hline $\mathrm{Mn}$ & $-0,264$ & $-0,136$ & 0,718 & 0,058 & 0,276 & $-0,097$ & 0,347 & 0,133 & 0,932 & $-0,150$ & . & & & & & & & & & & \\
\hline $\mathrm{Fe}$ & $-0,125$ & $-0,086$ & 0,357 & $-0,151$ & 0,751 & $-0,200$ & 0,376 & $-0,213$ & 0,600 & $-0,090$ & 0,670 & - & & & & & & & & & \\
\hline $\mathrm{Ni}$ & $-0,233$ & $-0,057$ & $-0,239$ & 0,014 & 0,021 & $-0,522$ & 0,350 & $-0,262$ & 0,124 & $-0,037$ & 0,100 & 0,072 & - & & & & & & & & \\
\hline $\mathrm{Cu}$ & $-0,138$ & $-0,048$ & 0,038 & $-0,203$ & 0,227 & 0,237 & 0,812 & $-0,067$ & 0,353 & $-0,028$ & 0,341 & 0,102 & 0,249 & - & & & & & & & \\
\hline $\mathrm{Zn}$ & $-0,371$ & $-0,202$ & 0,476 & 0,122 & 0,204 & $-0,342$ & 0,482 & 0,050 & 0,885 & $-0,200$ & 0,842 & 0,500 & 0,512 & 0,493 & - & & & & & & \\
\hline As & $-0,179$ & $-0,303$ & 0,391 & $-0,231$ & 0,392 & $-0,305$ & 0,599 & 0,144 & 0,304 & $-0,291$ & 0,378 & 0,231 & 0,336 & 0,579 & 0,521 & - & & & & & \\
\hline $\mathrm{Sr}$ & $-0,308$ & $-0,294$ & 0,752 & 0,448 & $-0,101$ & $-0,029$ & 0,042 & 0,768 & 0,643 & $-0,326$ & 0,666 & 0,192 & $-0,242$ & 0,078 & 0,484 & 0,191 & - & & & & \\
\hline $\mathrm{Cd}$ & $-0,261$ & 0,070 & 0,491 & $-0,103$ & 0,273 & $-0,400$ & 0,326 & $-0,181$ & 0,870 & 0,076 & 0,840 & 0,599 & 0,455 & 0,320 & 0,896 & 0,314 & 0,313 & - & & & \\
\hline $\mathrm{Pb}$ & $-0,374$ & $-0,174$ & 0,440 & 0,061 & 0,429 & $-0,406$ & 0,389 & $-0,180$ & 0,870 & $-0,182$ & 0,814 & 0,669 & 0,459 & 0,375 & 0,921 & 0,461 & 0,298 & 0,927 & - & & \\
\hline Tryptopha1 & $-0,023$ & 0,389 & $-0,179$ & $-0,543$ & 0,743 & $-0,246$ & 0,692 & $-0,341$ & $-0,054$ & 0,406 & $-0,001$ & 0,454 & 0,197 & 0,368 & 0,102 & 0,406 & $-0,363$ & 0,137 & 0,199 & - & \\
\hline Tyrosine & 0,105 & 0,256 & $-0,297$ & $-0,468$ & 0,817 & $-0,198$ & 0,557 & $-0,394$ & $-0,187$ & 0,273 & $-0,139$ & 0,501 & 0,139 & 0,216 & $-0,080$ & 0,239 & $-0,491$ & $-0,011$ & 0,092 & 0,928 & - \\
\hline
\end{tabular}

